\title{
Optimizing transfusion strategies in damage control resuscitation: current insights
}

This article was published in the following Dove Press journal: Journal of Blood Medicine

\author{
Timothy H Pohlman' \\ Alison M Fecher ${ }^{2}$ \\ Cecivon Arreola-Garcia ${ }^{3}$ \\ 'Department of Surgery, Lutheran \\ Hospital of Indiana, Fort Wayne, \\ IN, USA; ${ }^{2}$ Department of Surgery, \\ Lutheran Hospital of Indiana, Fort \\ Wayne, IN, USA; ${ }^{3}$ Department of \\ Surgery, Section of Acute Care \\ Surgery, Indiana University Health, \\ Indianapolis, IN, USA
}

Correspondence: Timothy H Pohlman Department of Surgery, Lutheran Hospital of Indiana, $7950 \mathrm{~W}$. Jefferson Blvd, Fort Wayne, IN 46804, USA Email tpohlman606@gmail.com

\begin{abstract}
From clinical and laboratory studies of specific coagulation defects induced by injury, damage control resuscitation (DCR) emerged as the most effective management strategy for hemorrhagic shock. DCR of the trauma patient who has sustained massive blood loss consists of 1) hemorrhage control; 2) permissive hypotension; and 3) the prevention and correction of trauma-induced coagulopathies, referred to collectively here as acute coagulopathy of trauma (ACOT). Trauma patients with ACOT have higher transfusion requirements, may eventually require massive transfusion, and are at higher risk of exsanguinating. Distinct impairments in the hemostatic system associated with trauma include acquired quantitative and qualitative platelet defects, hypocoagulable and hypercoagulable states, and dysregulation of the fibrinolytic system giving rise to hyperfibrinolysis or a phenomenon referred to as fibrinolytic shutdown. Furthermore, ACOT is a component of a systemic host defense dysregulation syndrome that bears several phenotypic features comparable with other acute systemic physiological insults such as sepsis, myocardial infarction, and postcardiac arrest syndrome. Progress in the science of resuscitation has been continuing at an accelerated rate, and clinicians who manage catastrophic blood loss may be incompletely informed of important advances that pertain to DCR. Therefore, we review recent findings that further characterize the pathophysiology of ACOT and describe the application of this new information to optimization of resuscitation strategies for the patient in hemorrhagic shock.
\end{abstract}

Keywords: trauma, shock, hemorrhage, resuscitation, coagulopathy, fibrinolysis, transfusion

\section{Introduction}

Massive hemorrhage from extensive trauma may rapidly overwhelm hemostatic systems that, arguably, evolved in response to lesser amounts of bleeding from more confined areas of injury. ${ }^{1}$ Many patients suffering a catastrophic loss of blood will develop a complex multisystem dysfunction syndrome, which includes specific defects in the coagulation system referred to collectively as acute coagulopathy of trauma (ACOT). ${ }^{2}$

ACOT is defined by clinical and laboratory findings suggesting acquired coagulopathy in patients with severe trauma. This pathophysiologic entity appears early after injury typically before any intervention has been instituted. This characteristic separates ACOT from coagulopathies secondary to dilution or consumption known to develop in trauma patients, particularly during resuscitation (referred to as resuscitationinduced coagulopathies.) ACOT is estimated to occur in $\sim 25 \%$ of severely injured patients (Injury Severity Score [ISS] > 25). In one prospective, observational study 
ACOT was found in $16.3 \%$ of all admitted trauma patients, including $11 \%$ of mildly injured patients (patients without physiological derangement or blood product administration). ${ }^{3}$

Coagulopathy in trauma patients is suggested by nonsurgical bleeding that appears, for example, from superficial abrasions, lacerations, and sites of vascular puncture, or by an increase in far more problematic surgical bleeding from sites of hemorrhage within major injuries. ACOT may manifest very soon after injury and is often present in the trauma patient prior to arriving at the hospital. Predictably, hemostatic failure in these particular circumstances substantially complicates management and significantly increases rates of adverse outcomes, including a fourfold increase in mortality. ${ }^{4}$

Hemostatic failure in the trauma patient must be anticipated and promptly diagnosed. Furthermore, the resuscitation of a patient in hemorrhagic shock incorporates hemostatic resuscitation strategies designed to rapidly correct coagulation system abnormalities and prevent further deterioration in the patient's capacity to form clot. Hemostatic resuscitation exists within the broader context of damage control resuscitation (DCR), which is characterized by certain additional clinical aspects. ${ }^{5}$ First, DCR involves rapid and often massive infusion of packed red blood cells (pRBCs) to expeditiously restore global oxygen delivery. Transfusion of this magnitude (referred to as "massive transfusion" or MT) has been arbitrarily characterized as the transfusion of $\geq 10$ units of pRBCs within a 24-h period. ${ }^{6}$ However, this definition is not considered a valid surrogate for severe hemorrhage ${ }^{7}$ since it does not accurately reflect the intensity of blood loss and fails to capture exsanguinating patients who die before receiving 10 units (survival bias). ${ }^{8}$ More recently, MT has been characterized as transfusion of $\geq 5$ units of RBCs over $4 \mathrm{~h}^{9}$ or $\geq 6$ units of RBC in $6 \mathrm{~h}$. However, an international forum on the treatment of trauma coagulopathy identified no fewer than 12 different definitions for MT. ${ }^{10}$ In general, newer definitions of MT delineate use of blood products within a more narrow time frame. ${ }^{6}$ For example, the critical administration threshold is defined as the transfusion of at least 3 units of pRBCs in any 1-h period of time, within the first 24 h. ${ }^{11}$ Second, DCR is carried out accepting a lower perfusion pressure as a resuscitation end point (referred to as permissive hypotension). Third, DCR protocols specify prompt recognition and management of profound homeostatic imbalances (eg, hypocalcemia and hypothermia) that arise in the course of resuscitation or in the aftermath of this intervention. And last, DCR is initiated while anticipating immediate hemorrhage control, which may be achieved by emergent surgical (including Resuscitative Endovascular
Balloon Occlusion of the Aorta placement), angiographic, or endoscopic approaches.

A coordinated effort of multiple disciplines has resulted in the development of DCR protocols that are associated with an increase in survival of the severely injured in concert with a reduction in costly waste of blood bank products. ${ }^{12-17}$ Trauma center verification (in particular, of Level 1 and Level 2 centers) by the American College of Surgeons Committee on Trauma is predicated on demonstration of both an organized capability to carry out DCR and a commitment to the process.

Although trauma patients account for $90 \%$ of those receiving this complex, resource-intensive, and potentially dangerous intervention, a specific discussion of DCR for trauma may be extended to treatment of significant blood loss for other reasons, including massive gastrointestinal bleeding, gynecological hemorrhagic crises, and intraoperative and postoperative hemorrhage complicating vascular, cardiovascular, and other complex surgical procedures. ${ }^{18,19}$ For example, treatment of severe postpartum hemorrhage (PPH) complicating high-risk obstetrical cases may be optimized when carried out by a multidisciplinary, rapid response team well-versed in the pathophysiology of hemorrhagic shock and the principles of DCR..$^{20,21}$

Here, we describe processes that destabilize the balance of interdependent effectors and modulators of coagulation and fibrinolysis associated with the acquisition of ACOT. Furthermore, we review therapeutic principles upon which correction of these pathological processes is achieved. However, the pathophysiology of hemorrhagic shock is not yet completely understood, and it is expected that the management of massive blood loss will continue to be significantly modified as further information derived from original investigation emerges.

\section{Cell-based model of clot formation}

Hemostasis is an exact balance between opposing pathways of coagulation and fibrinolysis. ${ }^{22}$ In response to injury, formation of thrombin occurs in four corresponding phases: ${ }^{.23,24}$ 1) "initiation", during which small amounts of coagulation factor (F) IX and FX are activated by exposed subendothelial tissue factor (TF) in the presence of constitutively activated FVII (FVIIa); 2) “amplification", in which FXa produces a small amount of thrombin that in turn activates FV, FVIII, FIX, and resting platelets; 3) "propagation", by which activated coagulation factors assemble on aggregating platelets to mediate formation of thrombin in amounts sufficient to convert fibrinogen into long noncovalently linked fibers (fibrin); and 4) stabilization through which fibrin is 
converted to a covalently linked polymer $^{23}$ (Figure 1A). Covalent cross-linking of fibrin fibers by thrombin-activated FXIII increases the elasticity of individual fibers, establishing the overall viscoelastic properties of a fibrin clot. ${ }^{25} \mathrm{~A}$ blood clot is a viscoelastic polymer that exhibits both the elastic properties of a spring and the viscous properties of a fluid. ${ }^{26}$ Furthermore, thrombin promotes resistance of formed clot to fibrinolytic degradation through activation of a plasminogenbound carboxypeptidase, thrombin-activatable fibrinolysis inhibitor (TAFI). ${ }^{27}$

Plasmin is the critical mediator of fibrinolysis. The accumulation of fibrin promotes activation of the fibrinolytic system by enhancing tissue plasminogen activator (tPA)mediated conversion of plasminogen to plasmin. Fibrinogen also promotes plasminogen activation but at a rate that is $\sim 100$-fold less than fibrin, which tends to concentrate fibrinolytic activity to fibrin clot. In addition to limiting extension of clots beyond sites of injury, plasmin mediates subsequent dissolution of clots once repair of injured tissue is established (Figure 1B).

Several endogenous systems regulate coagulation and fibrinolysis. Tissue factor pathway inhibitor (TFPI) modulates three cofactor complexes, TF-FVIIa, FXa-FVa, and FIXa-FVIIIa, depending on TFPI isoform. ${ }^{28,29}$ Inhibition of prothrombinase by TFPI $\alpha$ may have direct clinical relevance, ${ }^{30}$ although TFPI modulation of TF-VIIa complexes may be insufficient to control coagulation in extreme conditions. ${ }^{31}$ Activated protein $\mathrm{C}(\mathrm{aPC})^{32}$ in the presence of protein S, sphingolipids, and/or high-density lipoproteins inactivates FVa and FVIIIa. Consequently, tenase complex and prothrombinase complex formation diminish, and the conversion of prothrombin to thrombin is attenuated. aPC also promotes clot breakdown by blocking plasminogen activation inhibitor-1 (PAI-1)-mediated inhibition of fibrinolysis. ${ }^{33}$ Antithrombin (AT) inactivates thrombin, and to a lesser extent inhibits the activities of FXa, FIXa, FXIa, and FXIIa. The inactivation of thrombin by AT is accelerated several fold by binding of glycosaminoglycans, including heparin and heparin sulfate to AT, which induces a specific allosteric change in AT. ${ }^{34} \mathrm{AT}$, TFPI, and aPC suppress proinflammatory mediators as well. ${ }^{35}$

Thrombomodulin is an endothelial cell surface protein that couples the downregulation of coagulation and fibrinolysis by functioning as an essential cofactor in the activation of PC and TAFI. TAFI blocks fibrinolysis by cleaving plasmin-exposed lysine residues on fibrin clot, which limits tPA binding to fibrin, thereby reducing any further conversion of plasminogen to plasmin. Furthermore, TAFI inhibits complement anaphylatoxins C3a and C5a indicating a potentially important anti-inflammatory role for this carboxypeptidase in addition to a procoagulant function. ${ }^{36-38}$ Thrombin binding to thrombomodulin (TM) converts the substrate specificity of thrombin from fibrinogen to PC and TAFI. Thus, during downregulation of hemostasis under nonpathological conditions, the balance between coagulation and fibrinolysis is maintained. However, in trauma patients a systemic injury to the vascular endothelium results in the release of angiopoetin-2 (Ang-2) from endothelial cell Weibel-Palade bodies. ${ }^{39}$ Ang-2 has recently been demonstrated to bind to endothelial cell TM and thereby block thrombin-TM interactions. ${ }^{40}$ Whether Ang-2 binds soluble TM under these conditions has not yet been established. Loss of thrombin-mediated activation of PC and TAFI, in effect, decouples inhibition of coagulation and fibrinolysis. The persisting activity of these two pathways would then be determined by the relative effectiveness of other specific inhibitors.

In an unperturbed state, endothelial Ang-1 and Ang-2 maintain vascular homeostasis through tightly regulated interaction with the kinase receptor, Tie2 expressed on quiescent endothelial cells. In contrast, Ang-2, released from activated cells ECs, destabilizes vascular function. ${ }^{41}$ Ang-2-Tie 2 interactions activate the conical NF- $\kappa$ B signaling pathway leading to expression of proteins that mediate leukocyte firm adhesion and transmigration across the endothelial barrier. NF- $\kappa \mathrm{B}$ nuclear translocation under these conditions also promotes expression of IL- 6 and TNF- $\alpha$ in both plasma and lung. ${ }^{42,43}$ These systemic auto-inflammatory processes may be associated mechanistically with the development of trauma-induced acute respiratory distress syndrome (ARDS). ${ }^{44}$ Damage to the alveolar epithelium is considered the principle mechanism causing increased pulmonary permeability, permitting accumulation of edema fluid containing high concentrations of macromolecules in the alveoli. ${ }^{45}$ The breakdown of the alveolar-epithelial barrier is a consequence of multiple factors that include dysregulated inflammation, intense leukocyte infiltration, activation of procoagulant processes, cell death, and mechanical stretch. ${ }^{46}$

\section{Rapid assessment of hemostasis}

Conventional coagulation tests, such as prothrombin time, activated partial thromboplastin time, international normalized ratio, fibrinogen concentration, platelet count, and assays to detect fibrinolysis are performed on cell-free plasma samples at $37^{\circ} \mathrm{C}$. Typically, assays require up to 60 min to complete even though clinical conditions may be 
A Tissue factor pathway inhibitor (TFPI)
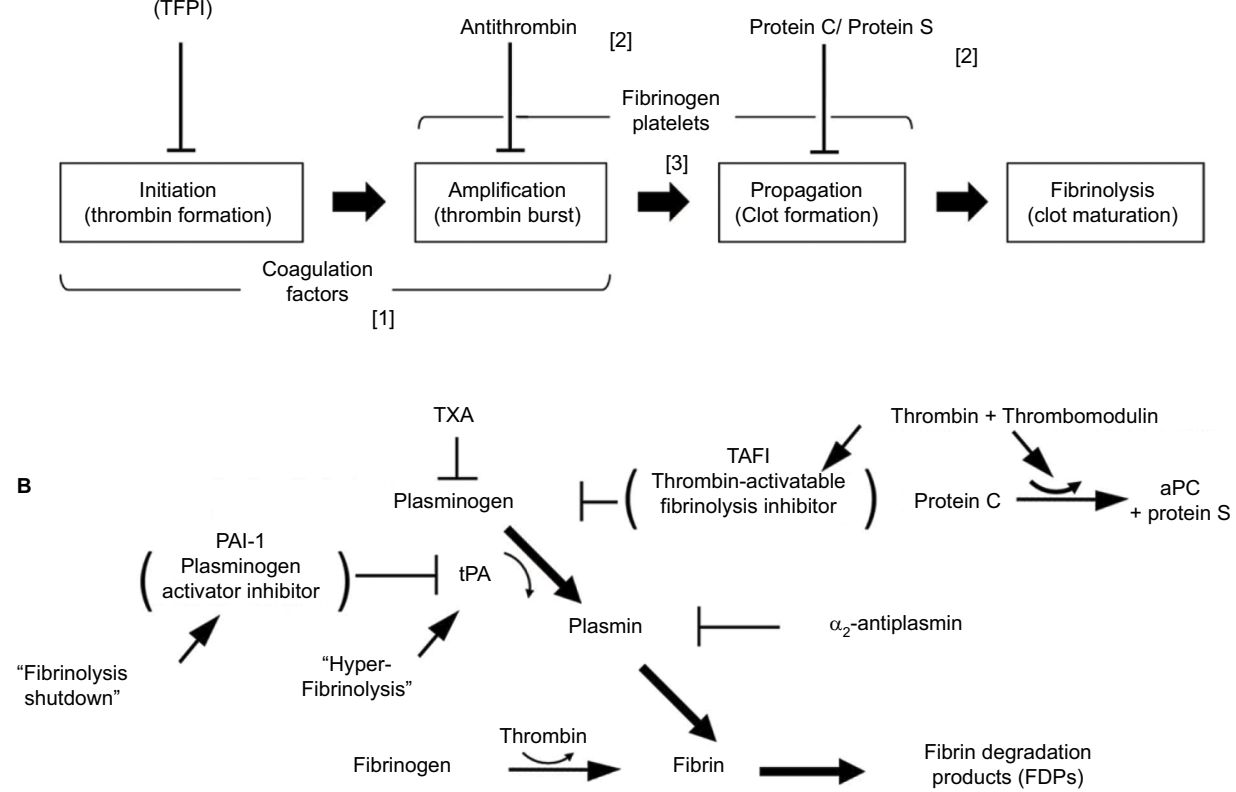

Figure I Normal hemostasis involves both coagulation and fibrinolysis regulated by several physiologic inhibitors . (A) Phases of a cell-based model of coagulation include "initiation" that occurs after exposure of TF in the presence of Vlla, a small amount of which is normally present in the circulation, followed by "priming" in which FXa produces a small amount of thrombin to activate FVIII, FV; and platelets, resulting in "propagation", involving assembly of activated coagulation factors on aggregating platelets to produce a thrombin burst on the surface of platelets that mediate conversion of fibrinogen to fibrin. Three endogenous anticoagulation systems modulate coagulation to prevent clot formation in excess (thrombosis) beyond the site of injury. These are predominately localized to expression on vascular endothelial surfaces. Trauma-associated coagulopathy is related to excess thrombomodulin (TM) expression resulting in high concentrations of activated protein C (aPC) and possibly to disruption of the endothelial glycocalyx with release of heparin-like proteoglycans that interact with antithrombin in a process referred to as auto-heparinization. A role for TFPI in trauma-associated coagulopathy has not been identified; however, experimentally, depletion of TFPI predisposes to disseminated intravascular coagulation, which has been suggested to be a mechanism of coagulopathy following trauma. (B) Fibrinolytic pathway and endogenous mediators that regulate fibrinolysis. Plasmin is generated from plasminogen by tPA and is controlled by several inhibitors, principally PAI-I. Upregulation of TM and thrombin-TM interactions increases thrombin-mediated activation of TAFI I,000-fold; elevated levels of aPC may promote fibrinolysis by limiting thrombin production and consequently TAFI activation. Hyperfibrinolysis associated with trauma is thought to occur after endothelial cell perturbation following injury with trauma-induced release of large amounts of tPA in association with downregulation of PAI-I. Fibrinolysis shutdown is thought to occur through trauma-mediated dysregulation of PA-I expression.

Abbreviations: AT, antithrombin; PC, protein C, tPA, tissue plasminogen activator; TF, tissue factor; TXA, tranexamic acid; PAI-I, plasminogen activation inhibitor-I.

changing rapidly, and conventional tests of coagulation have never been validated in bleeding trauma patients. ${ }^{47}$ The plasma half-life of thrombin is very short, which precludes measurement of plasma concentrations; therefore, other parameters have been used as evidence of thrombin generation in the systemic circulation, such as thrombinAT complex levels and soluble fibrin levels. Moreover, conventional evaluations of coagulation does not generally include an assessment of platelet function. ${ }^{48,49}$ In contrast, rheology-based coagulation tests quantify the viscoelasticity of clots in real time and may provide more clinically relevant data within 5-10 $\mathrm{min}$. In addition, these assays are readily repeated, and by superimposing tracings upon one another, we are able to detect important trends in the results of multiple decisions made during the course of a resuscitation that otherwise would not be apparent.

Viscoelastic hemostatic assays essentially integrate assessments of the kinetics of clot formation, the physical properties of the forming clot, which includes the clot elastic modulus (CEM), and the extent of fibrinolytic activity. CEM is a critical parameter defining clot flexibility to shear force.$^{50}$ Since whole blood is used in the assay, clots are a more realistic composition of platelets, fibrin, and erythrocytes compared with clots formed in conventional test done on plasma only.

A standard assay measures five parameters, which correlate with various phases of coagulation ${ }^{51-53}$ and certain coagulopathies (Figure 2). Viscoelastic hemostatic assays do not include a platelet count, and an evaluation of platelet function requires additional assay modules. Two systems, thromboelastography (TEG ${ }^{\circledR}$; Haemonetics Corp, Niles, IL, USA) and rotational thromboelastometry (ROTEM ${ }^{\circledR}$; Tem International $\mathrm{GmbH}$, Munich, Germany), are used in clinical laboratory or point-of-care (POC) coagulation testing. TEG and ROTEM both examine properties of hemostasis under low shear stress conditions. However, neither TEG 
A
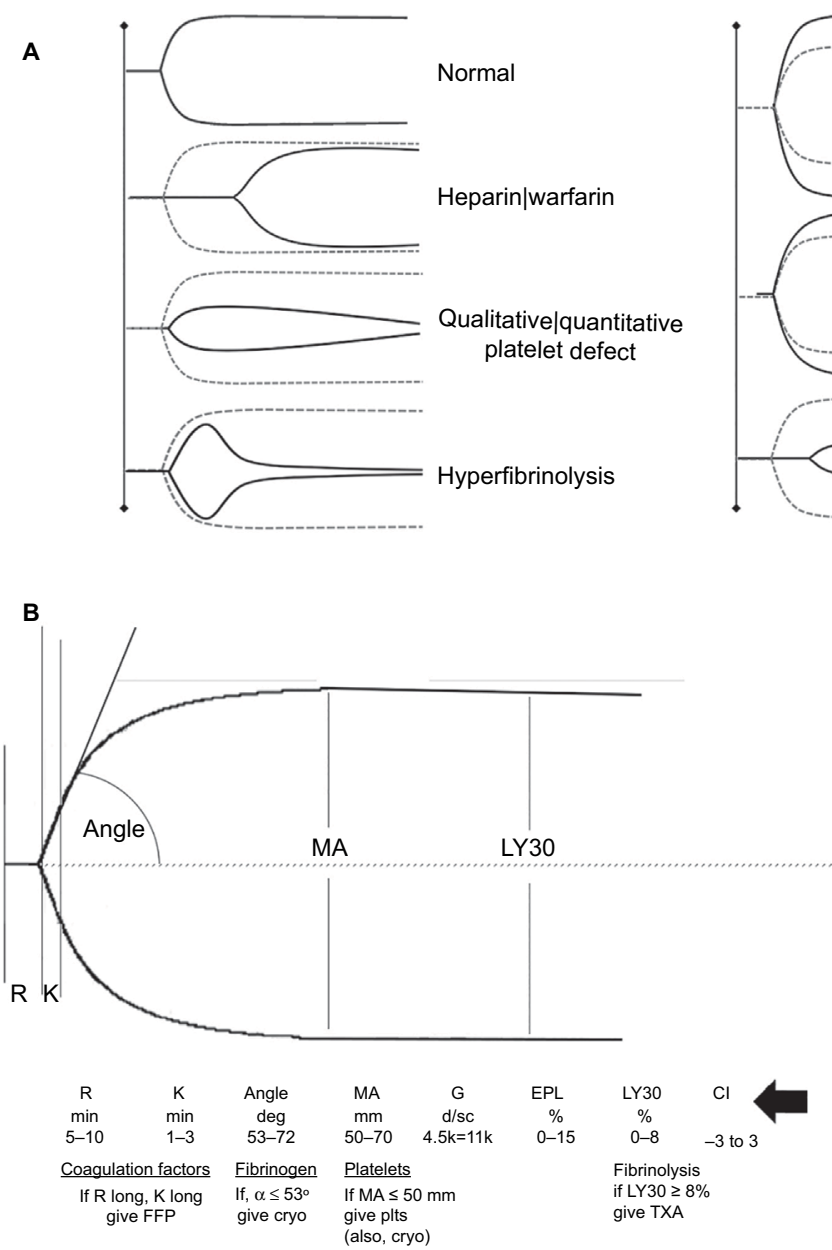

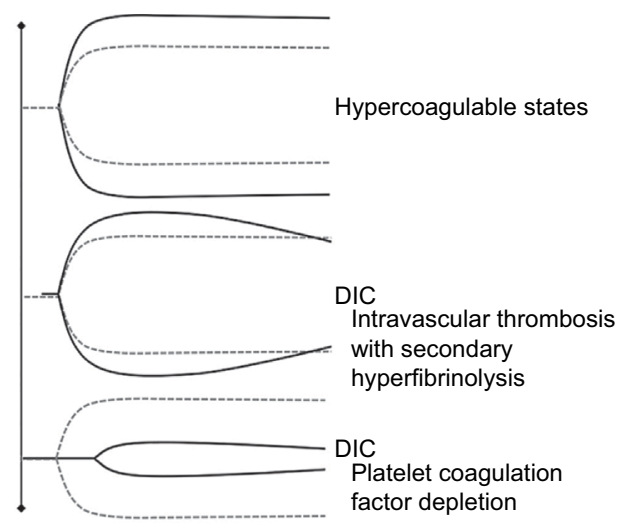

C

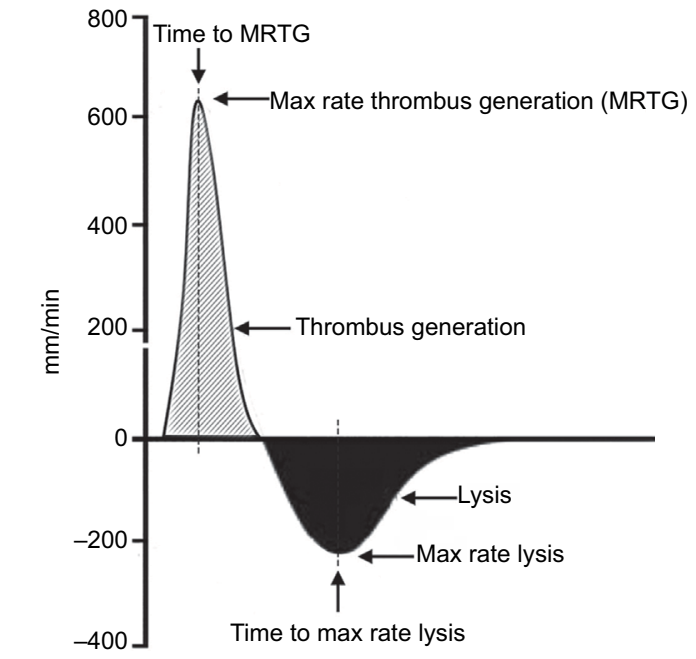

Figure 2 Thromboelastography $\left(\mathrm{TEG}^{\circledR}\right)$. (A) Schematic presentation of different viscoelastic tracings reflecting states of the coagulation system compared with normal. (B) Basic viscoelastic tracing with measured parameters and limits of normal for thromboelastography, correlated with different elements of the coagulation system ( $\mathrm{R}=$ reaction time, $\mathrm{K}=$ clot formation time, angle, $\mathrm{MA}=$ maximum amplitude, Ly30 = percent clot lysis $30 \mathrm{~m}$ after MA). Viscoelastic $\mathrm{k}$-time and angle correlate to some degree with fibrinogen concentration. However, the agreement between these parameters and fibrinogen levels determined by standard von Clauss assay is not sufficiently strong to be useful clinically. ${ }^{174-176}$ To overcome this limitation with TEG, the specific contributions of fibrinogen and platelets to clot strength can be determined with additional reagents (TEG; Functional Fibrinogen [Haemonetics Corp, Niles, IL, USA]). ${ }^{177}$ Using TEG, additional measures of clot strength can be computed. Coagulation index (Cl; black arrow) is derived from $\mathrm{R}$, $\mathrm{k}$-time, angle, and $\mathrm{MA}$, with a $\mathrm{Cl}>+3.0$ suggesting a hypercoagulable state and $\mathrm{Cl}<-3.0$ suggesting coagulopathy. The shear elastic module strength, designated $\mathrm{G}$, is a computer-generated quantity that reflects an integrated measure of clot strength. Conceptually, $\mathrm{G}$ is considered the most informative parameter of clot strength because it reflects the contributions of the enzymatic and platelet components of hemostasis. ${ }^{178,179}$ (C) Thrombus generation velocity curve is a mathematical first derivative of the TEG tracing, which provides additional information with respect to both thrombus formation and lysis. ${ }^{179}$ For example, velocity curve measures of fibrinolysis are stronger predictors of early transfusion of blood components, bleeding, and mortality after trauma compared with conventional rTEG values. In addition, the maximal rate of lysis is more rapidly available after arrival, which may facilitate earlier diagnosis and treatment of clinically significant hyperfibrinolysis. ${ }^{180}$

Abbreviations: rTEG, rapid thromboelastography; DIC, disseminated intravascular coagulation; EPL, estimated percent lysis; FFP, fresh frozen plasma; Cryo, cryoprecipitate; Plts, platelets; TXA, tranexamic acid.

nor ROTEM assesses the contribution of the endothelium to coagulation.

Rapid TEG $^{\circledR}$ (r-TEG) can be completed within $15 \mathrm{~min}$ compared with an average 30-45 min processing time for a standard TEG assay. In an r-TEG assay, samples are activated with $\mathrm{TF}$ in addition to kaolin which yields an activated clotting time, or TEG-ACT, in place of the reaction time (R-time). TEG-ACT may predict abnormalities that will appear later in the tracing. For example, ACT $>140$ s predicts a flattened angle and diminished MA, indicating almost immediately a requirement for cryoprecipitate and platelet transfusions that would not have been known. ${ }^{54}$ Data from a recent pragmatic, randomized clinical trial indicate now that utilization of a TEG-guided massive transfusion protocol (referred to as a "goal-directed" protocol) to resuscitate severely injured patients improves survival compared with massive transfusion guided by conventional coagulation assays and utilizes less plasma and platelet transfusions during the early phase of resuscitation. ${ }^{55}$ In addition, the fibrinogen assay component of TEG may detect fibrinolysis 
much earlier permitting more timely and appropriate utilization of antifibrinolytic therapy. ${ }^{56}$

\section{Acute coagulopathy of trauma}

Distinct impairments in the coagulation system characterize ACOT. These include acquired quantitative and qualitative platelet defects, hypocoagulable and hypercoagulable states, and dysregulation of the fibrinolytic system giving rise to $\mathrm{HF}$ or a phenomenon referred to as fibrinolytic shutdown. ${ }^{57} \mathrm{Of}$ interest, ACOT is a component of a systemic host defense dysregulation syndrome that bears several phenotypic features comparable with those of other acute systemic physiological insults, including sepsis, myocardial infarction, and postcardiac arrest syndrome. ${ }^{58}$

Defects in platelet function may be caused by injury, ${ }^{59}$ particularly traumatic brain injury (TBI), ${ }^{60-63}$ secondary to downregulation of platelet $\mathrm{P} 2 \mathrm{Y}_{12}$ and arachidonic acid receptors. ${ }^{60,64}$ The $\mathrm{P} 2 \mathrm{Y}_{12}$ receptor binds the platelet agonist ADP (which is blocked by a frequently prescribed anticoagulant, clopidogrel [Plavix ${ }^{\text {TM}}$; Bristol-Myers Squibb/Sanofi Pharmaceuticals Partnership Bridgewater, NJ, USA]). P2Y 12 inhibition correlates with the severity of TBI as well as TBI-related mortality. The mechanism responsible for TBI-induced $\mathrm{P} 2 \mathrm{Y}_{12}$ downregulation is not clearly defined, and this type of platelet dysfunction is often overlooked in the TBI patient who is bleeding, particularly when the platelet count is normal.

Two separate (yet conceivably overlapping) pathophysiological processes are proposed as the principal cause of coagulopathy in patients who are severely injured (ISS $\geq 25$ ). Disseminated intravascular coagulation (DIC) with a fibrinolytic phenotype is suggested by thrombocytopenia, increased fibrinogen/fibrin degradation product (FDP) levels, increased measured D-dimer, higher FDP:D-dimer ratios, ${ }^{5}$ increased prothrombin times, and diminished levels of endogenous inhibitors of intravascular coagulation and fibrinolysis (eg, AT and $\alpha 2$-antiplasmin, respectively). ${ }^{5,65}$ DIC-mediated coaguloapthy in the trauma patient requires diffuse intravascular generation of procoagulants induced by reperfusion injury in the setting of hemorrhagic shock. ${ }^{31,65}$ These procoagulants include microparticles (MPs) expressing TF, which are derived from platelets, ${ }^{66,67}$ erythrocytes,${ }^{68}$ possibly brain tissue, ${ }^{69,70}$ free circulating mitochondrial DNA, ${ }^{71}$ histone-complexed DNA fragments, ${ }^{72}$ and HMGB $1 .{ }^{73,74}$ Intravascular procoagulant activity is also augmented by decreased AT levels and diminished aPC pathway activity. ${ }^{75}$

In response to intravascular activation of coagulation, HF (in this setting referred to as secondary HF) with collateral fibrinogenolysis may occur in trauma patients as suggested by the elevated levels of plasmin- $\alpha 2$-antiplasmin complexes, D-dimer and FDPs. ${ }^{76-79}$ This is not a specific pathological process, but rather a compensatory process to counter intravascular clot formation. However, primary HF (and hyperfibrinogenolysis) due to a massive shock-induced release of tPA from vascular endothelium, which rapidly overwhelms PAI-1, may occur in this setting. ${ }^{80}$ Within minutes of arrival, an unsurvivable subtype of primary HF can be recognized on $r$-TEG tracing as a characteristic diamondshaped pattern. ${ }^{81}$ Intravascular coagulation in concert with either primary or secondary HF consumes endogenous inhibitors leading to further coagulofibrinolytic dysregulation, a defining characteristic of DIC. DIC results in consumption of platelets and coagulation factors, ${ }^{82}$ notably fibrinogen, which manifests clinically in the trauma patient as coagulopathy.

An alternative conjecture, shock-induced endotheliopathy (SHINE) $)^{83}$ posits diffuse injury to the endothelium and the endothelial glycocalyx due to whole-body ischemia-reperfusion (I/R) injury and massive sympatho-adrenergic discharge (the endothelium weighs $\sim 1 \mathrm{~kg}$ and covers a surface area of the vascular tree of $\sim 5,000 \mathrm{~m}^{2}$, which is equivalent to the surface area of an American football field ). A systemic hypoxia may also contribute to endothelial injury causing destabilization of homeostasis and barrier disruption by promoting release of angiopoietins, TF, PAI-1, soluble TM, vWF, and tPA. ${ }^{84}$ In severely injured patients, high levels of a marker of significant glycocalyx disruption, syndecan-1, can be detected in $\sim 5 \%$ of patients with ACOT. ${ }^{85}$ After adjusting for ISS, syndecan-1 independently predicts increased mortality. ${ }^{86}$ Damage to the luminal glycocalyx presumes release of constituents of this layer, such as proteoglycans, which in effect heparinize the bleeding trauma patient. Systemic endothelial cell activation is associated with disruption of TFPI, and aPC-mediated regulation of coagulation in concert with endothelial release of tPA and urokinase-type plasminogen activator (uPA). Evidence also exists for downregulation of other endogenous anticoagulant and anti-inflammatory pathways in this syndrome..$^{5,87-89}$

In trauma, fibrinolytic system dysfunction develops as either HF or fibrinolysis shutdown (also referred to as postinjury fibrinolysis resistance). Neither HF nor fibrinolysis shutdown necessarily correlates with ISS or the magnitude of shock, although the development of either one of these two hemostatic abnormalities is associated with increasing mortality. Unregulated release of tPA from activated endothelial cells is suggested as the cause of $\mathrm{HF}^{81,90-92}$ whereas massive release of PAI-1 from activated platelets ${ }^{93}$ may be the pathological basis of fibrinolysis shutdown. Also, impaired 
tPA generation due to SHINE is suggested as a contributing mechanism to fibrinolytic shutdown. Fibrinolytic shutdown is the most common form of fibrinolytic dysfunction occurring in $\sim 65 \%$ of trauma patients, whereas systemic HF develops in a much smaller percentage (18\%-20\%). ${ }^{93}$ However, HF has been reported to develop in up to $53 \%$ of a subgroup of severely injured patients who progress to massive transfusion. ${ }^{78,91,94,95}$ These observations argue against the early empiric use (within $3 \mathrm{~h}$ of injury) of tranexamic acid (TXA) in most acutely injured patients with the exception of patients undergoing massive transfusion. Empiric administration of TXA $3 \mathrm{~h}$ after injury is also proscribed by CRASH-2, ${ }^{96}$ although TXA is potentially permitted after $3 \mathrm{~h}$ from time of injury if viscoelastic assay demonstrates ongoing HF. ${ }^{97}$

Furthermore, a number of studies have been completed, or are ongoing that examine the use of TXA in other settings of massive hemorrhage. For example, antifibrinolytic drugs have been shown to reduce bleeding and the requirement for blood transfusions in patients who develop PPH, prompting the World Health Organization to recommend TXA for patients with established $\mathrm{PPH}$ refractory to conventional therapy. However, little is known about the prophylactic use of TXA to prevent PPH. A pragmatic, single-centered, double-blinded, randomized controlled pilot trial will assess the feasibility of administering a prophylactic dose of TXA to prevent the onset of $\mathrm{PPH}$ and is expected to be completed by December $2018 .^{98}$

HALT-IT is a much larger pragmatic, randomized, doubleblind, placebo controlled trial that will determine the effect of TXA on mortality, morbidity (rebleeding, nonfatal vascular events), blood transfusion, surgical intervention, and health status in patients with acute gastrointestinal bleeding. Replicating the power of the CRASH-2 study, HALT-IT involves $\sim 200$ centers in 40 countries, which will enroll 12,000 subjects. HALT-IT is expected to finish in 2020. ${ }^{99}$

TXA also inhibits platelet activation induced by plasmin and plasmin-mediated proinflammatory processes that may lead to multiple organ failure. ${ }^{100}$ Whether these associated effects of TXA impact survival are not known.

Hypofibrinogenemia is common in trauma but associations of trauma-induced hypofibrinogenemia with specific outcomes remain incompletely defined. ${ }^{101}$ Maintaining a fibrinogen level $>150-200 \mathrm{mg} / \mathrm{dL}$ is recommended for bleeding patients. ${ }^{102}$ Hypofibrinogenemia is observed more often in patients with severe extremity or pelvic fractures. Also, patients who are deeply acidotic or experience long delays before arriving at definitive care are more likely to have a low fibrinogen concentration. ${ }^{103}$ Low fibrinogen levels may be present prior to injury because of liver disease or develop secondary to severe liver injury or hypoxic liver injury (shock liver). ${ }^{104}$ Furthermore, acidosis and hypothermia may exacerbate injury-induced consumption of fibrinogen. ${ }^{105,106}$ FDPs interfere with fibrin covalent polymerization and clot stability and block ADP-induced platelet aggregation. ${ }^{107,108}$

Acquired FXIII deficiency secondary to hemorrhage or dilution by massive transfusion has been reported, ${ }^{109}$ and we consider this coagulation factor (which requires activation by thrombin and can be found concentrated in cryoprecipitate) to be crucial for correction of ACOT.1,110

\section{Coagulation and inflammation}

Although implementation of DCR principles has decreased overall mortality from exsanguination, ARDS and multiple organ dysfunction syndrome, two delayed complications of hemorrhagic shock, may be increasing as an unintended consequence. Hemorrhage followed by rapid reperfusion produce hepatic, renal, cardiovascular, and pulmonary dysfunction accompanied by acidosis and lactate accumulation. ${ }^{111-114}$ Upon restoration of blood flow, several plasma protein cascades are activated, including in addition to coagulation and fibrinolysis, complement and the kinin-kallikrein system, which mediate reperfusion-triggered inflammatory processes. For example, coagulation FXIIa integrates the contact activation plasma defense system with complement activation and the generation of proinflammatory anaphylatoxins, $\mathrm{C} 3 \mathrm{a}$, $\mathrm{C} 4 \mathrm{a}$, and $\mathrm{C} 5 \mathrm{a}$. This interaction is regulated by $\mathrm{C} 1$ inhibitor (Figure 3). Conceivably, individuals who express lower levels of this inhibitor, yet still within a normal range of phenotypic expression, would be more susceptible to I/R injury. In addition, the formation of neutrophil extracellular traps (NETs) has been suggested as an important mechanism in the development of a systemic auto-inflammatory reaction. ${ }^{115}$

HMGB1, the prototype damage-associated molecular pattern (DAMP) molecule, is a ubiquitous DNA-binding protein found in abundant amounts in human cells. HMGB1 is released from damaged tissue and circulates beyond the site of injury, engaging specific cell receptors, RAGE (receptor for advanced glycation end products), TLR-4 (toll-like receptor-4) and TLR-2 expressed on endothelial cells, and circulating mononuclear phagocytes. ${ }^{16,117}$ HMGB1 serum levels increase in hemorrhagic shock and trauma, ${ }^{118,119}$ suggesting plausibly that HMGB1 mediates in part pathophysiologic consequences of rapid reperfusion of ischemic tissue. Plasma levels of HMGB1 are increased 


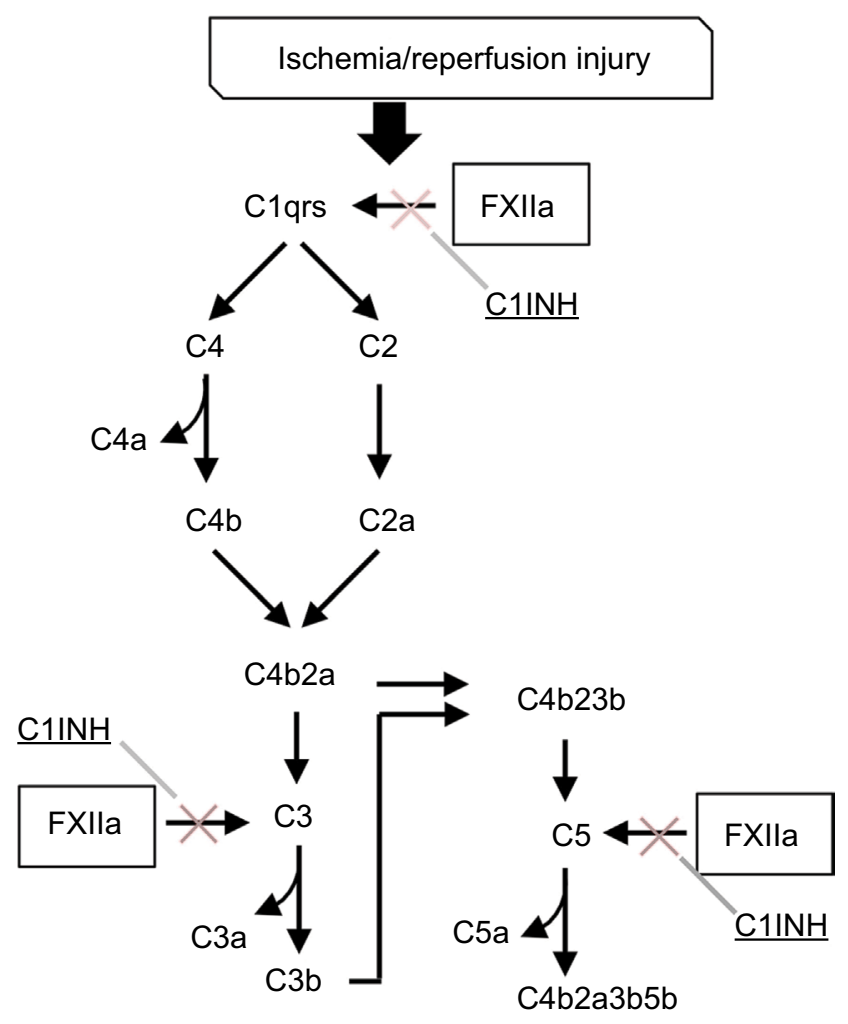

Figure 3 Complement-contact activation system interactions. Coagulation factor XII-induced increases in vascular permeability and proinflammatory activity are mediated by complement activation and are regulated in part by $\mathrm{Cl}$ inhibitor $(\mathrm{CIINH}){ }^{181}$ Attenuation of inflammation by $\mathrm{CIINH}$ has been described in several animal models of ischemia-reperfusion injury. ${ }^{182}$

within 30 min after severe trauma in humans and correlate with the severity of injury, extent of tissue hypoperfusion, early posttraumatic coagulofibrinolytic abnormalities, and auto-inflammatory responses. ${ }^{73,120,121}$ Nonsurviving trauma patients have significantly higher plasma levels of HMGB1 than survivors, and higher levels of HMGB1 are detectable in survivors who later develop organ injury such as acute lung injury and acute renal failure after DCR. Of note, HMGB1 demonstrates several interactions with the hemostatic system that may be the basis of the posttraumatic modulation of coagulation by hypoperfusion, which is characterized by TM upregulation, $\mathrm{PC}$ activation, inhibition of thrombin generation, and aPC-mediated consumption of PAI-1. 77,78 Thus, HMGB1 has been considered as both a clinical marker ${ }^{121}$ and a mediator ${ }^{121-123}$ of trauma-associated SIRS and organ failure.

RBCs stored for long periods release free hemoglobincontaining DAMP structures, which may contribute in unexpected ways to the adverse effects of massive transfusion. ${ }^{124}$

Recent observations have also shown that trauma leads to significant mitochondrial injury by a PI3-K-dependent pathway. This type of subcellular injury causes the release of mtDNA fragments ${ }^{125}$ into the local and systemic circulation, and that circulating levels of mtDNA may represent a highly sensitive (although not specific) indicator of the degree of systemic cellular injury following trauma associated with hemorrhagic shock. ${ }^{126}$ Furthermore, mtDNAs have also been shown to have significant proinflammatory properties as DAMPs leading to postresuscitation systemic auto-inflammatory disorders, which may be attenuated by PI3K pathway inhibition. ${ }^{127}$

\section{Damage control resuscitation}

In the hemorrhaging trauma patient, the decision to initiate DCR is predicated on apparent or anticipated life-threatening blood loss. Specifically, measured blood loss of a magnitude requiring management with this intervention is often associated with hypotension ( $\mathrm{SBP}<90 \mathrm{mmHg}$ ) and tachycardia (numerically a heart rate $>\mathrm{SBP}$ ). (Shock Index [SI] is defined as heart rate/SBP. For example, a trauma patient with a blood pressure of $94 / 60 \mathrm{mmHg}$ and heart rate of 110 beats $/$ min exhibits a $\mathrm{SI}=110 / 94=1.2$. Hemorrhagic shock is arbitrarily defined as $\mathrm{SI} \geq 0.9$.) This clinical state represents decompensated hemorrhagic shock, a relatively late finding in a progression to exsanguination. A clinical state more responsive to resuscitation exists when hemorrhage can be recognized before the volume of blood lost becomes life threatening. ${ }^{128-130}$ However, a diagnosis of compensated hemorrhagic shock in a patient may be challenging.

In 2013, a survey of American College of Surgeons Trauma Quality Improvement Program participants (which included 82 Level 1 and 42 Level 2 trauma centers) indicated that virtually all the sites surveyed relied on trauma surgeon discretion to activate a DCR protocol. The presence of hypotension and whether the immediate administration of uncrossed blood was required are somewhat more objective triggers for activation. ${ }^{131}$ Several scoring systems or algorithms have been developed to guide clinicians responsible for initiating DCR. ${ }^{6,132}$ Noninvasive measurement of muscle oxygenation based on optical spectroscopy (in contrast to near-infrared spectroscopy that determines transcutaneous oxygen saturation, an optical spectroscopy measurement does not require assumptions about the ratio of arterial to venous blood) may provide the most objective measure of shock and the best predictor of DCR. ${ }^{133-136}$

Incentives for refinement of policy in trauma centers regarding DCR can be demonstrated. As an example, an observational study comparing two time periods before (2005-2007) and after (2012-2014) the implementation of 
changes in trauma management protocols which included: use of goal-directed coagulation management, permissive hypotension, restrictive fluid resuscitation, and administration of TXA. This study showed reduction in incidence of massive transfusion and a reduction in the transfusion of RBCs and fresh frozen plasma (FFP) after implementation.

In addition to massive transfusion of pRBCs, DCR includes the balanced transfusion of plasma and platelets (plasma:platelets:RBC $=1: 1: 1$ ). For example in the Pragmatic, Randomized Optimal Platelet and Plasma Ratios trial, mortality from exsanguination decreased by $\sim 35 \%$ in patients transfused with a 1:1:1 ratio compared with a lower 1:1:2 ratio. ${ }^{137}$ DCR also can be "goal-directed" by applying POC viscoelastic coagulation testing. ${ }^{138}$ In practical terms, resuscitation begins with empiric transfusion of components in a fixed 1:1:1 ratio and is followed by transfusions of specific blood components, in certain amounts, at distinct time intervals, all determined by the patient's coagulation profile. The supposition that goal-directed DCR is superior to empiric fixed component ratio-directed DCR with respect to both patient outcome and resource utilization was recently examined in a randomized controlled trial. Compared with DCR of patients characterized by conventional tests of coagulation, TEG-guided goal-directed DCR improves survival and utilizes less plasma and platelet transfusions during the early phase of resuscitation. ${ }^{55}$

Platelet transfusions are an essential element of DCR, although under these conditions, the efficacy of empiric platelet transfusions have not yet been proven. ${ }^{139}$ Platelet transfusions pose distinct challenges including variable availability, contamination risks, eventual immunological sensitization, and others. ${ }^{140}$ Platelet storage at room temperature $\left(24^{\circ} \mathrm{C}\right)$ increases the chance of bacterial contamination (estimated to occur in one of every 3,000 platelet units) and increases the risk of transfusion-associated sepsis in recipients. ${ }^{141}$ Even though techniques to reduce pathogens contaminating platelet transfusion packs have proven to be quite effective, the success of this advance was lessened after extensive damage done to platelet function under these conditions became apparent. ${ }^{142}$

One unit of platelets obtained by apheresis contains $\sim 6 \times 10^{11}$ platelets and will increase a platelet count by $\sim 30,000-60,000 / \mu \mathrm{L}$ in a $70 \mathrm{~kg}$ nonhemorrhaging patient. ${ }^{110}$ Platelets are suspended in plasma. Thus, one unit provides $500 \mathrm{mg}$ of fibrinogen as well as other coagulation factors but also adds a risk of plasma-mediated febrile nonhemolytic transfusion and allergic reactions. ${ }^{143}$

Plasma as a blood bank component may be supplied as FFP; FP-24; so-called liquid, never frozen plasma; pooled detergent-treated plasma; or lyophilized plasma. The difference between FFP and FP-24, the two most common forms of plasma used, is the length of time between donor phlebotomy and when FFP and FP-24 are placed into $-18^{\circ} \mathrm{C}$ storage. In the USA and Canada, the designations FFP and FP-24 mean plasma is frozen within $8 \mathrm{~h}$ or within 24 $\mathrm{h}$, respectively. In Australia, plasma obtained by apheresis can be considered FFP only if frozen within $6 \mathrm{~h}$, whereas plasma separated from whole blood can be considered FFP if frozen within $18 \mathrm{~h} .{ }^{144}$

FVIII is reduced in FP-24 compared with FFP but remains above $30 \%$, which is sufficient to support coagulation. FP-24 is associated with a lower incidence of transfusion-related acute lung injury (TRALI) compared with FFP, and FP-24 is favored due to often complex logistics of transporting blood donations to blood centers from remote donation sites. FFP and FP-24 may be prepared by separation from a single unit donation of whole blood, yielding $200-250 \mathrm{~mL}$, or from apheresis of a single donor (400-600 mL). FFP or FP-24 is prepared for transfusion by thawing over several minutes at $34^{\circ} \mathrm{C}-37^{\circ} \mathrm{C}$. If these components are not transfused, they are not refrozen but are stored thawed $4^{\circ} \mathrm{C}$ for up to 4 days more. FVIII decays to $\sim 40 \%$ of normal; the decline in other coagulation factors by 5 days is comparable between thawed FFP and FP-24, although there is a more significant fall in FVII in thawed FP-24. ${ }^{145}$ Most trauma centers use thawed plasma for hemostatic resuscitation to be able to begin plasma transfusion immediately. ${ }^{146}$

Solvent-/detergent-treated pooled human plasma (octaplasLG®; Octapharma USA Inc, Hoboken, NJ, USA) is manufactured by pooling plasma of the same blood type from $\sim 650-1,500$ individuals at a time. Plasma is treated with detergent to inactivate enveloped viruses, and prions are removed by affinity chromatography. Pooled plasma treated in this way has a lower rate of pathogen transmission, and due to dilution of any prevailing anti-HLA and anti-HNA antibodies, these plasma preparations when compared with FFP or FP-24 are associated with smaller risks of TRALI and posttransfusion thrombocytopenia. ${ }^{147}$ Both Protein S and $\alpha 2$-antiplasmin are susceptible to detergent degradation, which potentially increases, respectively, the thrombotic and fibrinolytic activity of plasma prepared in this manner. ${ }^{148}$ Coagulation factor levels after 5 days of storage of thawed solvent-/detergent-treated pooled plasma are essentially the same as found in thawed single-donor plasma. ${ }^{149}$ In the US, the FDA currently approves use of octaplast for acquired factor-deficiency coagulopathies due to liver disease or that develop during the course of cardiovascular surgical procedures and liver transplantation. ${ }^{150}$ 
Until a recipient's blood type is determined, group $A B$ plasma is considered the "universal donor" plasma type to use empirically. Blood bank inventories of AB plasma, however, are routinely sparse. Therefore, plasma of this blood group type is never maintained thawed and consequently never immediately available at the beginning of resuscitation. ${ }^{146}$ Thus, in place of AB plasma, thawed group A plasma is transfused empirically when resuscitation is initiated. ${ }^{151-153}$ The risk of $\mathrm{ABO}$ blood group mismatch transfusion reaction is decreased by the fact that the most common encountered blood group in a recipient will be group A, and anti-B antibodies in group A donated plasma, which can be screened for (but typically are not), generally are low, particularly in plasma of North American males $>50$ years of age.

Reconstituted lyophilized plasma is another source of this blood component that may be used immediately for a recipient of any blood type because of dilution and neutralization of anti-A and anti-B hemagglutinins. This type of plasma preparation is useful logistically to medical support systems of armed services.

Because fibrinogen plays a critical role in traumatic hemorrhage, early repletion of fibrinogen is advocated. ${ }^{154,155}$ Several international guidelines for DCR specify fibrinogen infusion for plasma fibrinogen levels $<150-200 \mathrm{mg} / \mathrm{dL}$ or for TEG or ROTEM signs of hypofibrinogenemia (or possibly acquired dysfibrinogenemia). In the USA, cryoprecipitate (cryo) is the principal source of fibrinogen. ${ }^{156}$ Other coagulation factors enriched in cryo include von Willebrand factor, FVIII, and FXIII, and these plausibly contribute to hemostatic resuscitation.

Cryo is prepared by centrifugation of a slowly thawed unit of FFP and resuspension of the precipitate in a smaller volume of plasma, which is then frozen again at $-18^{\circ} \mathrm{C}$. This represents $\sim 30 \%$ of the fibrinogen (200-300 mg) from the original unit of FFP, but in much higher concentration because of a much smaller volume of plasma (10-20 mL). For transfusion, this preparation is rethawed and pooled with multiple donors. Typically, five single units are pooled into one before issue. An adult dose comprises two pools (10 single units total), which should increase plasma fibrinogen levels by $\sim 100 \mathrm{mg} / \mathrm{dL}$. Platelet membrane MPs, generated by the plasma freeze-thaw cycling, are concentrated in the precipitate, ${ }^{157}$ although it is not known if MPs formed under these conditions retain thrombotic or inflammatory potential.

In Europe, saline-reconstituted purified fibrinogen concentrate has largely replaced cryo in hemostatic resuscitation protocols for hemorrhagic shock. Although several advantages to fibrinogen concentrate over cryo in this setting appear evident, ${ }^{156}$ to date a significant clinical benefit or measurable cost-effectiveness of fibrinogen concentrate compared with cryo remain unproven. The Fibrinogen Early In Severe Trauma studY (FEISTY), ${ }^{155}$ a multicenter, randomized controlled trial comparing fibrinogen concentrate to cryo for fibrinogen supplementation in traumatic hemorrhage, is expected to finish enrollment by June 2018 . Whether the coadministration of FXIII concentrate ${ }^{109,158-161}$ potentiates fibrinogen concentrate also is unknown.

Prothrombin complex concentrates (PCCs) include vitamin K-dependent factors, FII, FVII, FIX, and FX. PCC products are considered either three-factor PCCs (containing a negligible concentration of FVII) or four-factor PCCs (with a higher concentration of FVII). Most newer PCC products should be considered six-factor PCCs because these contain two additional vitamin $\mathrm{K}$ covalently modified proteins, protein $\mathrm{C}$ and protein $\mathrm{S}$. Thrombotic complications associated with PCCs include venous thromboembolism, DIC, microvascular thrombosis, and myocardial infarction. ${ }^{162}$ Although these agents have specific indications for reversal of pharmacological anticoagulation in trauma patients, the use and timing of PCCs for management of ACOT remains to be defined.

Empiric treatment of patients with blunt and penetrating trauma with high doses of human recombinant FVIIa (rFVIIa) does not decrease mortality significantly but increases the risk of arterial thromboembolic events (eg, coronary artery thrombosis), especially among the elderly. ${ }^{163}$

\section{Acidosis and hypothermia}

Hypoperfusion of tissue and organs due to hemorrhagic shock produces lactic acidosis. Acidemia diminishes platelet activation, decreases coagulation factor enzymatic activity, and depletes substrate through enhanced fibrinogenolysis. ${ }^{106}$ In addition, the presence of excess hydrogen ion destabilizes crucial interactions between phospholipid platforms in platelets that are activated and coagulation factor complexes that have formed, further diminishing coagulation potential in the patient suffering from hemorrhagic shock. ${ }^{164}$

Reversal of lactic acidosis is frequently used as an end point indicating when resuscitation should be terminated. During DCR of a patient in whom there exists an expected elevated anion gap (AG) metabolic acidosis, the relationship between change $(\Delta)$ in AG and serum bicarbonate levels $\left(\triangle \mathrm{AG}: \Delta \mathrm{HCO}_{3}\right.$ ) may reveal unsuspected mixed metabolic acid-base disorders, ${ }^{165}$ which distort lactic acidosis as an end 
point. $\triangle \mathrm{AG}: \Delta \mathrm{HCO}_{3}{ }^{-}$will fall between 0.8 and 1.2 if no other complicating metabolic process is occurring. A $\triangle \mathrm{AG}: \Delta \mathrm{HCO}_{3}^{-}$ $<0.7$ suggests an additional hyperchloremic, nongap metabolic acidosis that often develops, for example, in patients treated inappropriately with large volumes of normal saline. Conversely, a $\triangle \mathrm{AG}: \Delta \mathrm{HCO}_{3}^{-}>1.2$ may indicate the presence of metabolic alkalosis (eg, lactic acidosis in a patient with preexisting COPD). A very high $\triangle \mathrm{AG}: \Delta \mathrm{HCO}_{3}{ }^{-}$ratio should suggest rhabdomyolysis complicating hemorrhagic shockinduced lactic acidosis ${ }^{166}$ or severe hypophosphatemia. ${ }^{167} \mathrm{We}$ cautiously treat acidosis $(\mathrm{pH}<7.2)$ with $\mathrm{NaHCO}_{3}$ to reverse impairment in myocardial contractility. This improves global oxygen delivery and accelerates correction of a base deficit.

Hypothermia frequently complicates coagulopathy in trauma patients. A decrease in core body temperature suppresses the enzymatic specificity constants of coagulation factors in the hemostatic pathway. Thus, each $1^{\circ} \mathrm{C}$ decrease in core temperature reduces coagulation factor activity by $\sim 10 \%-15 \%$, which is exacerbated by factor depletion secondary to dilution or consumption. ${ }^{168}$ However, hypothermia also inhibits endogenous anticoagulant activity (eg, thrombinTM-protein C pathway) as well as coagulation factor activity. A more important explanation for hypothermia-related coagulopathy is inhibition of von Willebrand factor-platelet GPIb-IX-V interactions, which mediate platelet adherence to damaged subendothelium. ${ }^{169}$

Hypothermia can be prevented by infusion of warm fluids both during the prehospital phase and resuscitation phase of treatment of a patient in hemorrhagic shock. Restoring perfusion and oxygen delivery will also reestablish endogenous heat generation. Resuscitation and damage control surgery should be performed in shock rooms and operating rooms, respectively, that are maintained at very warm temperatures, notwithstanding discomfort for providers.

\section{Resuscitation-induced coagulopathy}

During DCR, reduced circulating ionized calcium and magnesium develop from citrate toxicity that occurs as a result of transfusion of citrate-containing blood components. A healthy adult liver metabolizes up to $3 \mathrm{~g}$ of citrate every 5 min (approximately the amount in two units of pRBCs). However, exceptionally high transfusion rates, often reached during DCR, exceed this unimpaired capacity to clear citrate, while preexisting liver disease, impaired hepatic function from hypothermia, or severe traumatic liver injury may reduce citrate metabolism. ${ }^{170}$ Citrate toxicity-mediated divalent cation deficiencies are exacerbated by dilution of the patients circulat- ing ionized calcium. ${ }^{171}$ Furthermore, preexisting liver disease or hypothermia-induced impairment of hepatic function may reduce citrate metabolism and exacerbate hypocalcemia and hypomagnesemia. Citrate accumulation during resuscitation and citrate-mediated hypocalcemia are made worse by dilution of calcium by resuscitation fluids that do not contain this divalent cation. Hypocalcemia reduces myocardial contractility and impairs maintenance of vasomotor tone. Hypomagnesemia also develops due to citrate accumulation and dilution. Hypomagnesemia and hypocalcemia are associated with disruption of myocardial repolarization characterized by a prolonged QT interval and a risk for development of "torsades de pointes". We administer one ampule of intravenous calcium chloride empirically when we activate our DCR protocol. We administer additional calcium chloride throughout resuscitation as massive transfusion of citrate-containing components continues.

\section{Conclusion}

Hemostasis and inflammation are critical elements of host defense. The activation, regulation, and coordinated interaction of these systems are controlled predominately by mediators expressed by vascular endothelium. An extensive number of careful laboratory and clinical investigations identify endothelial cell dysfunction as the principal cause of a systemic physiologic dysfunction syndrome, which contributes, in part, to ACOT. ACOT substantially increases rates of trauma mortality and is an independent predictor of other adverse outcomes, including higher amounts of blood component transfusion. ACOT cannot be considered a single entity, however, and hemostatic failure associated with serious injury and hemorrhagic shock is arguably the sum of potentially several disturbed host mechanisms. Research agendas that focus on these undeniably complex hematologic and auto-inflammatory pathologies in the trauma patient (Table 1) have been assigned the highest priority by experts in trauma critical care. ${ }^{172}$ For example, we believe the adoption by the FDA of acquired hypofibrinogenemia or dysfibrinogenemia as an indication for fibrinogen concentrate will have a substantial positive effect on DCR in the future. Also, we predict further examination of the different changes in the fibrinolytic system in trauma patients, and how these changes modify the activity of other plasma host defense systems (complement, contact activation, and NET formation) may suggest additional targets for intervention during DCR. And, we anticipate that advances in the science of transfusion medicine will have a substantial impact on future DCR protocols. For example, a remarkable synthetic platelet 
Table I Representative examples of recently completed or ongoing clinical trials in trauma and critical care

\begin{tabular}{|c|c|c|c|c|}
\hline Title & Study designs & Enrollment & Start date & URL \\
\hline $\begin{array}{l}\text { Polyheme }(\mathrm{R}) \text { in } \mathrm{HS} \text { beginning } \\
\text { in the prehospital setting }\end{array}$ & $\begin{array}{l}\text { Randomized|open } \\
\text { label|treatment (Phase III) }\end{array}$ & Null & Null & https://ClinicalTrials.gov/show/NCT00076648 \\
\hline $\begin{array}{l}\text { REVIVE: reducing } \\
\text { exsanguination via in vivo } \\
\text { expandable foam }\end{array}$ & $\begin{array}{l}\text { Nonrandomized|open } \\
\text { label|treatment (Phase III) }\end{array}$ & 40 & Dec-2018 & https://ClinicalTrials.gov/show/NCT02880163 \\
\hline $\begin{array}{l}\text { Philadelphia immediate } \\
\text { transport in penetrating } \\
\text { trauma trial }\end{array}$ & $\begin{array}{l}\text { Randomized|double- } \\
\text { blinded|health services } \\
\text { research }\end{array}$ & I,036 & Jun-2018 & https://ClinicalTrials.gov/show/NCT0282/364 \\
\hline $\begin{array}{l}\text { Bedside visual analysis of } \\
\text { sublingual microcirculation in } \\
\text { shock patients }\end{array}$ & $\begin{array}{l}\text { Observational| } \\
\text { prospective|treatment }\end{array}$ & 50 & Feb-2018 & https://ClinicalTrials.gov/show/NCT03406598 \\
\hline $\begin{array}{l}\text { Shock, whole blood, and } \\
\text { assessment of TBI S.W.A.T. } \\
\text { (LITES TO 2) }\end{array}$ & $\begin{array}{l}\text { Observational|prospective|t } \\
\text { reatment }\end{array}$ & 1,050 & Feb-2018 & https://ClinicalTrials.gov/show/NCT03402035 \\
\hline $\begin{array}{l}\text { Prothrombin concentrate } \\
\text { complex for HS following } \\
\text { severe trauma }\end{array}$ & $\begin{array}{l}\text { Randomized|triple- } \\
\text { blinded|treatment (Phase III) }\end{array}$ & 350 & Nov-2017 & https://ClinicalTrials.gov/show/NCT032I 8722 \\
\hline $\begin{array}{l}\text { Sternal intraosseous } \\
\text { transfusion of autologous } \\
\text { whole blood: }\end{array}$ & $\begin{array}{l}\text { Observational|case- } \\
\text { control|prospective }\end{array}$ & 30 & Nov-2016 & https://ClinicalTrials.gov/show/NCT02924792 \\
\hline $\begin{array}{l}\text { Preservation and } \\
\text { resuscitation (EPR) for } \\
\text { cardiac arrest from trauma }\end{array}$ & $\begin{array}{l}\text { Nonrandomized|open } \\
\text { label|treatment (Phase II) }\end{array}$ & 20 & Oct-2016 & https://ClinicalTrials.gov/show/NCT0I042015 \\
\hline $\begin{array}{l}\text { Blood and plasma in } \\
\text { Norwegian physician-staffed } \\
\text { helicopter EMSs }\end{array}$ & Observational|prospective & 400 & Jun-2016 & https://ClinicalTrials.gov/show/NCT0278495I \\
\hline $\begin{array}{l}\text { Prehospital lyophilized plasma } \\
\text { for traumatic coagulopathy } \\
\text { (PREHO-PLYO) }\end{array}$ & $\begin{array}{l}\text { Randomized|parallel|open } \\
\text { label|treatment (Phase III) }\end{array}$ & 140 & Apr-2016 & https://ClinicalTrials.gov/show/NCT027368/2 \\
\hline $\begin{array}{l}\text { Nitroglycerine for poor } \\
\text { peripheral perfusion due } \\
\text { to HS }\end{array}$ & $\begin{array}{l}\text { Non } \\
\text { randomized|parallel|open } \\
\text { label (Phase II) }\end{array}$ & 100 & Mar-2016 & https://ClinicalTrials.gov/show/NCT0323592I \\
\hline $\begin{array}{l}\text { Remote ischemic } \\
\text { conditioning on trauma/HS }\end{array}$ & $\begin{array}{l}\text { Randomized|triple- } \\
\text { blinded|supportive care }\end{array}$ & 50 & May-20I5 & https://ClinicalTrials.gov/show/NCT0207/290 \\
\hline $\begin{array}{l}\text { Danger response in } \\
\text { polytrauma patients }\end{array}$ & $\begin{array}{l}\text { Observational|cohort|pros } \\
\text { pective }\end{array}$ & $\mathrm{I}, 000$ & Sep-20I4 & https://ClinicalTrials.gov/show/NCT02682550 \\
\hline $\begin{array}{l}\text { Effects of traumatic HS } \\
\text { and resuscitation on the } \\
\text { microcirculation }\end{array}$ & $\begin{array}{l}\text { Observational|cohort|prospe } \\
\text { ctive (Phase II) }\end{array}$ & 50 & Jul-2014 & https://ClinicalTrials.gov/show/NCT021III09 \\
\hline $\begin{array}{l}\text { Control of major bleeding } \\
\text { after trauma }\end{array}$ & $\begin{array}{l}\text { Randomized|open } \\
\text { label|treatment }\end{array}$ & 144 & Apr-2014 & https://ClinicalTrials.gov/show/NCT0I838863 \\
\hline $\begin{array}{l}\text { Phase } 2 c \text { dose comparison } \\
\text { study of MP4OX in trauma }\end{array}$ & $\begin{array}{l}\text { Randomized|quad- } \\
\text { blinded|treatment (Phase II) }\end{array}$ & 0 & Dec-2013 & https://ClinicalTrials.gov/show/NCT0I 973504 \\
\hline Comparison of compensatory & Observational|cohort|pros & 42 & Sep-2013 & https://ClinicalTrials.gov/show/NCT0I 935427 \\
\hline
\end{tabular}

reserve index to intravascular volume change and stroke volume

Polydatin injectable (HW6)

for shock treatment

Field trial of hypotensive versus standard resuscitation for hemorrhagic shock after trauma

Development of an algorithm for prediction of onset of hemodynamic instability in humans pective

Randomized|tripleblinded|treatment (Phase II) Randomized|parallel assignment|blinded|treatment (Phase II)

Observational|caseonly|prospective 
Table I Representative examples of recently completed or ongoing clinical trials in trauma and critical care

\begin{tabular}{|c|c|c|c|c|}
\hline Title & Study designs & Enrollment & Start date & URL \\
\hline $\begin{array}{l}\text { Phase Ilb study of MP4OX in } \\
\text { traumatic HS patients }\end{array}$ & $\begin{array}{l}\text { Randomized|parallel } \\
\text { assignment|quad- } \\
\text { blinded|treatment (Phase II) }\end{array}$ & 348 & May-20II & https://ClinicalTrials.gov/show/NCT0I262196 \\
\hline $\begin{array}{l}\text { The cutoff point for Caval } \\
\text { index and its correlation } \\
\text { with central venous pressure } \\
\text { and plasma lactate level } \\
\text { for assessing patients in } \\
\text { hypovolemic hemorrhagic } \\
\text { states }\end{array}$ & $\begin{array}{l}\text { Observational|case- } \\
\text { only|prospective }\end{array}$ & 106 & Apr-20II & https://ClinicalTrials.gov/show/NCT0I74I8I8 \\
\hline $\begin{array}{l}\text { Plasma for patients requiring } \\
\text { emergency surgery }\end{array}$ & $\begin{array}{l}\text { Randomized|group } \\
\text { assignment|triple- } \\
\text { blinded|treatment (Phase IV) }\end{array}$ & 40 & Mar-20II & https://ClinicalTrials.gov/show/NCT0I221389 \\
\hline $\begin{array}{l}\text { Biological response of trauma } \\
\text { patients to standard trauma } \\
\text { resuscitation therapy }\end{array}$ & $\begin{array}{l}\text { Randomized|parallel } \\
\text { assignment|quad- } \\
\text { blinded|treatment }\end{array}$ & 5 & Jan-2010 & https://ClinicalTrials.gov/show/NCT0I239680 \\
\hline $\begin{array}{l}\text { Comparison of rTEG and } \\
\text { conventional coagulation } \\
\text { testing for haemostatic } \\
\text { resuscitation in trauma }\end{array}$ & $\begin{array}{l}\text { Randomized|parallel } \\
\text { assignment|open } \\
\text { label|diagnostic }\end{array}$ & 114 & Sep-2010 & https://ClinicalTrials.gov/show/NCT0I536496 \\
\hline
\end{tabular}

Abbreviations: HS, hemorrhagic shock; TBI, traumatic brain injury; EPR, emergency preservation and resuscitation; EMS, emergency medical services; rTEG, rapid thromboelastography.

surrogate nearly at hand, SynthoPlate ${ }^{\mathrm{TM}}$, which is based on expression of clinically relevant biocompatible liposomal platforms, promises to relieve many of the general problems that plague platelet transfusions presently. ${ }^{173}$ Development of novel therapies based on results from these investigations and many others will continue to be the basis for further optimization of DCR for catastrophic blood loss.

\section{Acknowledgment}

The authors thank Dr Pradeesh George for helpful suggestions and insightful discussions during drafting of the manuscript. His extensive knowledge of the subject substantially focused this review.

\section{Disclosure}

The authors report no conflicts of interest in this work.

\section{References}

1. Pohlman TH, Walsh M, Aversa J, Hutchison EM, Olsen KP, Lawrence Reed R. Damage control resuscitation. Blood Rev. 2015;29(4):251-262.

2. Chang R, Cardenas JC, Wade CE, Holcomb JB. Advances in the understanding of trauma-induced coagulopathy. Blood. 2016;128(8):1043-1049.

3. MacLeod JB, Winkler AM, McCoy CC, Hillyer CD, Shaz BH. Early trauma induced coagulopathy (ETIC): prevalence across the injury spectrum. Injury. 2014;45(5):910-915.

4. Schochl H, Schlimp CJ, Voelckel W. Potential value of pharmacological protocols in trauma. Curr Opin Anaesthesiol. 2013;26(2):221-229.
5. Oshiro A, Yanagida Y, Gando S, Henzan N, Takahashi I, Makise H. Hemostasis during the early stages of trauma: comparison with disseminated intravascular coagulation. Crit Care. 2014;18(2):R61.

6. Chang R, Holcomb JB. Optimal fluid therapy for traumatic hemorrhagic shock. Crit Care Clin. 2017;33(1):15-36.

7. Rahbar E, Fox EE, del Junco DJ, et al. Early resuscitation intensity as a surrogate for bleeding severity and early mortality in the PROMMTT study. J Trauma Acute Care Surg. 2013;75(1 Suppl 1):S16-23.

8. Rahbar MH, del Junco DJ, Huang H, et al. A latent class model for defining severe hemorrhage: experience from the PROMMTT study. J Trauma Acute Care Surg. 2013;75(1 Suppl 1):S82-88.

9. Oldroyd JC, Venardos KM, Aoki NJ, et al. Improving outcomes for hospital patients with critical bleeding requiring massive transfusion: the Australian and New Zealand Massive Transfusion Registry study methodology. BMC Res Notes. 2016;9(1):457.

10. Levi M, Fries D, Gombotz H, et al. Prevention and treatment of coagulopathy in patients receiving massive transfusions. Vox Sang. 2011;101(2):154-174.

11. Savage SA, Zarzaur BL, Croce MA, Fabian TC. Redefining massive transfusion when every second counts. J Trauma Acute Care Surg. 2013;74(2):396-400.

12. Brohi K, Cohen MJ, Ganter MT, et al. Acute coagulopathy of trauma: hypoperfusion induces systemic anticoagulation and hyperfibrinolysis. J Trauma. 2008;64(5):1211-1217.

13. Brohi K, Singh J, Heron M, Coats T. Acute traumatic coagulopathy. $J$ Trauma. 2003;54(6):1127-1130.

14. Hess JR, Dutton RB, Holcomb JB, Scalea TM. Giving plasma at a 1:1 ratio with red cells in resuscitation: who might benefit? Transfusion. 2008;48(8):1763-1765.

15. Holcomb JB, Jenkins D, Rhee P, et al. Damage control resuscitation: directly addressing the early coagulopathy of trauma. J Trauma. 2007;62(2):307-310.

16. McLaughlin DF, Niles SE, Salinas J, et al. A predictive model for massive transfusion in combat casualty patients. J Trauma. 2008;64(2 Suppl):S57-S63. 
17. Niles SE, McLaughlin DF, Perkins JG, et al. Increased mortality associated with the early coagulopathy of trauma in combat casualties. $J$ Trauma. 2008;64(6):1459-1463.

18. Mesar T, Larentzakis A, Dzik W, Chang Y, Velmahos G, Yeh DD. Association between ratio of fresh frozen plasma to red blood cells during massive transfusion and survival among patients without traumatic injury. JAMA Surg. 2017;152(6):574-580.

19. Farooq N, Galiatsatos P, Aulakh JK, Higgins C, Martinez A. Massive transfusion practice in non-trauma related hemorrhagic shock. J Crit Care. 2018;43:65-69.

20. American College of Obstetricians and Gynecologists Committee on Patient Safety and Quality Improvement. Committee Opinion No. 590: preparing for clinical emergencies in obstetrics and gynecology. Obstet Gynecol. 2014;123(3):722-725.

21. Weisbrod AB, Sheppard FR, Chernofsky MR, et al. Emergent management of postpartum hemorrhage for the general and acute care surgeon. World J Emerg Surg. 2009;4:43.

22. Matsumoto T, Nogami K, Shima M. Simultaneous measurement of thrombin and plasmin generation to assess the interplay between coagulation and fibrinolysis. Thromb Haemost. 2013;110(4):761-768.

23. Hoffman M, Monroe DM 3rd. A cell-based model of hemostasis. Thromb Haemost. 2001;85(6):958-965.

24. Monroe DM, Hoffman M, Roberts HR. Platelets and thrombin generation. Arterioscler Thromb Vasc Biol. 2002;22(9):1381-1389.

25. Wolberg AS. Thrombin generation and fibrin clot structure. Blood Rev. 2007;21(3):131-142.

26. Huang CC, Shih CC, Liu TY, Lee PY. Assessing the viscoelastic properties of thrombus using a solid-sphere-based instantaneous force approach. Ultrasound Med Biol. 2011;37(10):1722-1733.

27. Van de Wouwer M, Collen D, Conway EM. Thrombomodulin-protein C-EPCR system: integrated to regulate coagulation and inflammation. Arterioscler Thromb Vasc Biol. 2004;24(8):1374-1383.

28. Wood JP, Ellery PE, Maroney SA, Mast AE. Biology of tissue factor pathway inhibitor. Blood. 2014;123(19):2934-2943

29. Mast AE. Tissue factor pathway inhibitor: multiple anticoagulant activities for a single protein. Arterioscler Thromb Vasc Biol. 2016;36(1):9-14.

30. Maroney SA, Mast AE. New insights into the biology of tissue factor pathway inhibitor. J Thromb Haemost. 2015;13(Supp1 1):S200-S207.

31. Gando S, Otomo Y. Local hemostasis, immunothrombosis, and systemic disseminated intravascular coagulation in trauma and traumatic shock. Crit Care. 2015;19:72.

32. Martin FA, Murphy RP, Cummins PM. Thrombomodulin and the vascular endothelium: insights into functional, regulatory, and therapeutic aspects. Am J Physiol Heart Circ Physiol. 2013;304(12):H1585-H1597.

33. Christiaans SC, Wagener BM, Esmon CT, Pittet JF. Protein C and acute inflammation: a clinical and biological perspective. Am J Physiol Lung Cell Mol Physiol. 2013;305(7):L455-L466.

34. Schedin-Weiss S, Richard B, Olson ST. Kinetic evidence that allosteric activation of antithrombin by heparin is mediated by two sequential conformational changes. Arch Biochem Biophys. 2010;504(2):169-176.

35. Levy JH, Sniecinski RM, Welsby IJ, Levi M. Antithrombin: antiinflammatory properties and clinical applications. Thromb Haemost. 2016;115(4):712-728.

36. Campbell WD, Lazoura E, Okada N, Okada H. Inactivation of C3a and C5a octapeptides by carboxypeptidase $\mathrm{R}$ and carboxypeptidase N. Microbiol Immunol. 2002;46(2):131-134.

37. Myles T, Nishimura T, Yun TH, et al. Thrombin activatable fibrinolysis inhibitor, a potential regulator of vascular inflammation. J Biol Chem. 2003;278(51):51059-51067.

38. Nishimura T, Myles T, Piliponsky AM, Kao PN, Berry GJ, Leung LL. Thrombin-activatable procarboxypeptidase $B$ regulates activated complement C5a in vivo. Blood. 2007;109(5):1992-1997.

39. Weng HB, Li S. Early changes of plasma angiopoietin-2 in patients with multiple trauma. World J Emerg Med. 2011;2(4):287-290.

40. Daly C, Qian X, Castanaro C, et al. Angiopoietins bind thrombomodulin and inhibit its function as a thrombin cofactor. Sci Rep. 2018;8(1):505.
41. Lomas-Neira J, Venet F, Chung CS, Thakkar R, Heffernan D, Ayala A. Neutrophil-endothelial interactions mediate angiopoietin-2-associated pulmonary endothelial cell dysfunction in indirect acute lung injury in mice. Am J Respir Cell Mol Biol. 2014;50(1):193-200.

42. Hughes DP, Marron MB, Brindle NP. The antiinflammatory endothelial tyrosine kinase Tie2 interacts with a novel nuclear factor-kappaB inhibitor ABIN-2. Circ Res. 2003;92(6):630-636.

43. Tadros A, Hughes DP, Dunmore BJ, Brindle NP. ABIN-2 protects endothelial cells from death and has a role in the antiapoptotic effect of angiopoietin-1. Blood. 2003;102(13):4407-4409.

44. Terpstra ML, Aman J, van Nieuw Amerongen GP, Groeneveld AB. Plasma biomarkers for acute respiratory distress syndrome: a systematic review and meta-analysis*. Crit Care Med. 2014;42(3):691-700.

45. Zinter MS, Spicer A, Orwoll BO, et al. Plasma angiopoietin-2 outperforms other markers of endothelial injury in prognosticating pediatric ARDS mortality. Am J Physiol Lung Cell Mol Physiol. 2016;310(3):L224-L231.

46. Herrero R, Sanchez G, Lorente JA. New insights into the mechanisms of pulmonary edema in acute lung injury. Ann Transl Med. 2018;6(2):32.

47. Hajjarian Z, Tripathi MM, Nadkarni SK. Optical Thromboelastography to evaluate whole blood coagulation. J Biophotonics. 2015;8(5):372-381.

48. Johansson PI. Coagulation monitoring of the bleeding traumatized patient. Curr Opin Anaesthesiol. 2012;25(2):235-241.

49. Weeder PD, Porte RJ, Lisman T. Hemostasis in liver disease: implications of new concepts for peri-operative management. Transfus Med Rev. 2014;28(3):107-113.

50. Weisel JW. Biophysics. Enigmas of blood clot elasticity. Science. 2008;320(5875):456-457.

51. Johansson PI, Stissing T, Bochsen L, Ostrowski SR. Thrombelastography and tromboelastometry in assessing coagulopathy in trauma. Scand J Trauma Resusc Emerg Med. 2009;17:45.

52. Johansson PI, Svendsen MS, Salado J, Bochsen L, Kristensen AT. Investigation of the thrombin-generating capacity, evaluated by thrombogram, and clot formation evaluated by thrombelastography of platelets stored in the blood bank for up to 7 days. Vox Sang. 2008;94(2):113-118.

53. Kawasaki J, Katori N, Kodaka M, Miyao H, Tanaka KA. Electron microscopic evaluations of clot morphology during thrombelastography. Anesth Analg. 2004;99(5):1440-1444.

54. Gonzalez E, Moore EE, Moore HB. Management of traumainduced coagulopathy with thrombelastography. Crit Care Clin. 2017;33(1):119-134.

55. Gonzalez E, Moore EE, Moore HB, et al. Goal-directed hemostatic resuscitation of trauma-induced coagulopathy: a pragmatic randomized clinical trial comparing a viscoelastic assay to conventional coagulation assays. Ann Surg. 2016;263(6):1051-1059.

56. Harr JN, Moore EE, Chin TL, et al. Viscoelastic hemostatic fibrinogen assays detect fibrinolysis early. Eur J Trauma Emerg Surg. 2015;41(1):49-56.

57. Moore EE, Moore HB, Gonzalez E, et al. Postinjury fibrinolysis shutdown: rationale for selective tranexamic acid. J Trauma Acute Care Surg. 2015;78(6 Suppl 1):S65-S69.

58. Wada T. Coagulofibrinolytic changes in patients with post-cardiac arrest syndrome. Front Med (Lausanne). 2017;4:156.

59. Ramsey MT, Fabian TC, Shahan CP, et al. A prospective study of platelet function in trauma patients. J Trauma Acute Care Surg. 2016;80(5):726-732.

60. Davis PK, Musunuru H, Walsh M, et al. Platelet dysfunction is an early marker for traumatic brain injury-induced coagulopathy. Neurocrit Care. 2013;18(2):201-208.

61. Windelov NA, Sorensen AM, Perner A, et al. Platelet aggregation following trauma: a prospective study. Blood Coagul Fibrinolysis. 2014;25(1):67-73.

62. Wohlauer MV, Moore EE, Droz NM, et al. Hemodilution is not critical in the pathogenesis of the acute coagulopathy of trauma. J Surg Res. 2012;173(1):26-30. 
63. Wohlauer MV, Moore EE, Thomas S, et al. Early platelet dysfunction: an unrecognized role in the acute coagulopathy of trauma. J Am Coll Surg. 2012;214(5):739-746.

64. Castellino FJ, Chapman MP, Donahue DL, et al. Traumatic brain injury causes platelet adenosine diphosphate and arachidonic acid receptor inhibition independent of hemorrhagic shock in humans and rats. $J$ Trauma Acute Care Surg. 2014;76(5):1169-1176.

65. Gando S, Sawamura A, Hayakawa M. Trauma, shock, and disseminated intravascular coagulation: lessons from the classical literature. Ann Surg. 2011;254(1):10-19.

66. Park MS, Owen BA, Ballinger BA, et al. Quantification of hypercoagulable state after blunt trauma: microparticle and thrombin generation are increased relative to injury severity, while standard markers are not. Surgery. 2012;151(6):831-836.

67. Park MS, Xue A, Spears GM, et al. Thrombin generation and procoagulant microparticle profiles after acute trauma: a prospective cohort study. J Trauma Acute Care Surg. 2015;79(5):726-731.

68. Matijevic N, Wang YW, Wade CE, et al. Cellular microparticle and thrombogram phenotypes in the Prospective Observational Multicenter Major Trauma Transfusion (PROMMTT) study: correlation with coagulopathy. Thromb Res. 2014;134(3):652-658.

69. Tian Y, Salsbery B, Wang M, et al. Brain-derived microparticles induce systemic coagulation in a murine model of traumatic brain injury. Blood. 2015;125(13):2151-2159.

70. Nekludov M, Mobarrez F, Gryth D, Bellander BM, Wallen H. Formation of microparticles in the injured brain of patients with severe isolated traumatic brain injury. J Neurotrauma. 2014;31(23):1927-1933.

71. Zhang Q, Raoof M, ChenY, etal. Circulating mitochondrial DAMPs cause inflammatory responses to injury. Nature. 2010;464(7285):104-107.

72. Johansson PI, Windelov NA, Rasmussen LS, Sorensen AM, Ostrowski SR. Blood levels of histone-complexed DNA fragments are associated with coagulopathy, inflammation and endothelial damage early after trauma. J Emerg Trauma Shock. 2013;6(3):171-175.

73. Cohen MJ, Brohi K, Calfee CS, et al. Early release of high mobility group box nuclear protein 1 after severe trauma in humans: role of injury severity and tissue hypoperfusion. Crit Care. 2009;13(6):R174.

74. Giannoudis PV, Mallina R, Harwood P, Perry S, Sante ED, Pape HC. Pattern of release and relationship between HMGB-1 and IL-6 following blunt trauma. Injury. 2010;41(12):1323-1327.

75. Treutiger CJ, Mullins GE, Johansson AS, et al. High mobility group 1 B-box mediates activation of human endothelium. J Intern Med. 2003;254(4):375-385.

76. Levrat A, Gros A, Rugeri L, et al. Evaluation of rotation thrombelastography for the diagnosis of hyperfibrinolysis in trauma patients. $\mathrm{Br}$ J Anaesth. 2008;100(6):792-797.

77. Schochl H, Frietsch T, Pavelka M, Jambor C. Hyperfibrinolysis after major trauma: differential diagnosis of lysis patterns and prognostic value of thrombelastometry. J Trauma. 2009;67(1):125-131.

78. Schochl H, Voelckel W, Maegele M, Solomon C. Trauma-associated hyperfibrinolysis. Hamostaseologie. 2012;32(1):22-27.

79. Longstaff C, Kolev K. Basic mechanisms and regulation of fibrinolysis. J Thromb Haemost. 2015;13(Suppl 1):S98-105.

80. Cotton BA, Harvin JA, Kostousouv V, et al. Hyperfibrinolysis at admission is an uncommon but highly lethal event associated with shock and prehospital fluid administration. JTrauma Acute Care Surg. 2012;73(2):365-370.

81. Chapman MP, Moore EE, Moore HB, et al. The "Black Diamond": Rapid thrombelastography identifies lethal hyperfibrinolysis. JTrauma Acute Care Surg. 2015;79(6):925-929.

82. Allard S, Green L, Hunt BJ. How we manage the haematological aspects of major obstetric haemorrhage. Br J Haematol. 2014;164(2):177-188.

83. Johansson P, Stensballe J, Ostrowski S. Shock induced endotheliopathy (SHINE) in acute critical illness - a unifying pathophysiologic mechanism. Crit Care. 2017;21(1):25.

84. White NJ, Ward KR, Pati S, Strandenes G, Cap AP. Hemorrhagic blood failure: oxygen debt, coagulopathy, and endothelial damage. JTrauma Acute Care Surg. 2017;82(6S Suppl 1):S41-S49.
85. Ostrowski SR, Johansson PI. Endothelial glycocalyx degradation induces endogenous heparinization in patients with severe injury and early traumatic coagulopathy. J Trauma Acute Care Surg. 2012;73(1):60-66.

86. Johansson PI, Ostrowski SR. Acute coagulopathy of trauma: balancing progressive catecholamine induced endothelial activation and damage by fluid phase anticoagulation. Med Hypotheses. 2010;75(6):564-567.

87. Hayakawa M, Gando S, Ono Y, Wada T, Yanagida Y, Sawamura A Fibrinogen level deteriorates before other routine coagulation parameters and massive transfusion in the early phase of severe trauma: a retrospective observational study. Semin Thromb Hemost. 2015;41(1):35-42.

88. Hayakawa M, Sawamura A, Gando S, et al. Disseminated intravascular coagulation at an early phase of trauma is associated with consumption coagulopathy and excessive fibrinolysis both by plasmin and neutrophil elastase. Surgery. 2011;149(2):221-230.

89. Yanagida Y, Gando S, Sawamura A, et al. Normal prothrombinase activity, increased systemic thrombin activity, and lower antithrombin levels in patients with disseminated intravascular coagulation at an early phase of trauma: comparison with acute coagulopathy of traumashock. Surgery. 2013;154(1):48-57.

90. Cardenas JC, Matijevic N, Baer LA, Holcomb JB, Cotton BA, Wade $\mathrm{CE}$. Elevated tissue plasminogen activator and reduced plasminogen activator inhibitor promote hyperfibrinolysis in trauma patients. Shock. 2014;41(6):514-521

91. Cardenas JC, Wade CE, Holcomb JB. Mechanisms of trauma-induced coagulopathy. Curr Opin Hematol. 2014;21(5):404-409.

92. Chapman MP, Moore EE, Ramos CR, et al. Fibrinolysis greater than $3 \%$ is the critical value for initiation of antifibrinolytic therapy. $J$ Trauma Acute Care Surg. 2013;75(6):961-967.

93. Moore HB, Moore EE, Huebner BR, et al. Fibrinolysis shutdown is associated with a fivefold increase in mortality in trauma patients lacking hypersensitivity to tissue plasminogen activator. J Trauma Acute Care Surg. 2017;83(6):1014-1022.

94. Davenport R. Pathogenesis of acute traumatic coagulopathy. Transfusion. 2013;53(Suppl 1):23S-27S.

95. Raza I, Davenport R, Rourke C, et al. The incidence and magnitude of fibrinolytic activation in trauma patients. J Thromb Haemost. 2013;11(2):307-314.

96. Shakur H, Roberts I, Bautista R, et al. Effects of tranexamic acid on death, vascular occlusive events, and blood transfusion in trauma patients with significant haemorrhage (CRASH-2): a randomised, placebo-controlled trial. Lancet. 2010;376(9734):23-32.

97. Moore HB, Moore EE, Gonzalez E, et al. Hyperfibrinolysis, physiologic fibrinolysis, and fibrinolysis shutdown: the spectrum of postinjury fibrinolysis and relevance to antifibrinolytic therapy. J Trauma Acute Care Surg. 2014;77(6):811-817.

98. Alam AQ. Use of TXA to Prevent Postpartum Hemorrhage (TAPPH-1) Available from: https:/clinicaltrials.gov/ct2/show/NCT03069859?ter $\mathrm{m}=\mathrm{NCT} 03069859 \& \mathrm{rank}=1$. Accessed May 18, 2018.

99. Shakur H. Haemorrhage Alleviation With Tranexamic Acid- Intestinal System (HALT-IT); NCT01658124. 2018. Available from: https:// clinicaltrials.gov/ct2/show/NCT01658124?term=HALT-IT\&rank=1. Accessed May 5, 2018.

100. Panteli M, Pountos I, Giannoudis PV. Pharmacological adjuncts to stop bleeding: options and effectiveness. Eur J Trauma Emerg Surg. 2016;42(3):303-310.

101. Rourke C, Curry N, Khan S, et al. Fibrinogen levels during trauma hemorrhage, response to replacement therapy, and association with patient outcomes. J Thromb Haemost. 2012;10(7):1342-1351.

102. Besser MW, MacDonald SG. Acquired hypofibrinogenemia: current perspectives. J Blood Med. 2016;7:217-225.

103. Hagemo JS, Stanworth S, Juffermans NP, et al. Prevalence, predictors and outcome of hypofibrinogenaemia in trauma: a multicentre observational study. Crit Care. 2014;18(2):R52.

104. vanDeWater L, Carr JM, Aronson D, McDonagh J. Analysis of elevated fibrin(ogen) degradation product levels in patients with liver disease. Blood. 1986;67(5):1468-1473. 
105. Martini J, Maisch S, Pilshofer L, Streif W, Martini W, Fries D. Fibrinogen concentrate in dilutional coagulopathy: a dose study in pigs. Transfusion. 2014;54(1):149-157.

106. Martini WZ. Coagulopathy by hypothermia and acidosis: mechanisms of thrombin generation and fibrinogen availability. $J$ Trauma. 2009; 67(1):202-208.

107. Hunt BJ, Segal H. Hyperfibrinolysis. J Clin Pathol. 1996;49(12):958.

108. Stachurska J, Latallo Z, Kopec M. Inhibition of platelet aggregation by dialysable fibrinogen degradation products (FDP). Thromb Diath Haemorrh. 1970;23(1):91-98.

109. Levy JH, Greenberg C. Biology of Factor XIII and clinical manifestations of Factor XIII deficiency. Transfusion. 2013;53(5):1120-1131.

110. Andreason CL, Pohlman TH. Damage control resuscitation for catastrophic bleeding. Oral Maxillofac Surg Clin North Am. 2016;28(4):553-568.

111. Papadopoulos D, Siempis T, Theodorakou E, Tsoulfas G. Hepatic ischemia and reperfusion injury and trauma: current concepts. Arch Trauma Res. 2013;2(2):63-70.

112. Satterly SA, Martin M, Wingerd M, Hempel J, Hoffer Z, Stallings JD. Flutamide fails to reduce resuscitation requirements in a porcine ischemia-reperfusion model. J Surg Res. 2013;184(1):472-479.

113. Singer M. Critical illness and flat batteries. Crit Care. 2017;21(Suppl 3):309.

114. Waxman K. Shock: ischemia, reperfusion, and inflammation. New Horiz. 1996;4(2):153-160.

115. Jorch SK, Kubes P. An emerging role for neutrophil extracellular traps in noninfectious disease. Nat Med. 2017;23(3):279-287.

116. Raymond SL, Holden DC, Mira JC, et al. Microbial recognition and danger signals in sepsis and trauma. Biochim Biophys Acta. 2017;1863(10 Pt B):2564-2573.

117. Wagner N, Dieteren S, Franz N, et al. Ethyl pyruvate ameliorates hepatic injury following blunt chest trauma and hemorrhagic shock by reducing local inflammation, NF-kappaB activation and HMGB1 release. PLoS One. 2018;13(2): 0192171.

118. Eppensteiner J, Davis RP, Barbas AS, Kwun J, Lee J. Immunothrombotic activity of damage-associated molecular patterns and extracellular vesicles in secondary organ failure induced by trauma and sterile insults. Front Immunol. 2018;9:190.

119. Levy RM, Mollen KP, Prince JM, et al. Systemic inflammation and remote organ injury following trauma require HMGB1. Am J Physiol Regul Integr Comp Physiol. 2007;293(4):R1538-R1544.

120. Eskici ZM, Acikgoz S, Piskin N, et al. High mobility group B1 levels in sepsis and disseminated intravascular coagulation. Acta Biochim Pol. 2012;59(4):561-566.

121. Hatada T, Wada H, Nobori T, et al. Plasma concentrations and importance of high mobility group box protein in the prognosis of organ failure in patients with disseminated intravascular coagulation. Thromb Haemost. 2005;94(5):975-979.

122. Gando S. Microvascular thrombosis and multiple organ dysfunction syndrome. Crit Care Med. 2010;38(2 Suppl):S35-S42.

123. Ito $\mathrm{T}$, Kawahara $\mathrm{K}$, Nakamura $\mathrm{T}$, et al. High-mobility group box 1 protein promotes development of microvascular thrombosis in rats. $J$ Thromb Haemost. 2007;5(1):109-116.

124. Zettel KR, Dyer M, Raval JS, et al. Aged human stored red blood cell supernatant inhibits macrophage phagocytosis in an HMGB1 dependent manner after trauma in a murine model. Shock. 2017;47(2):217-224.

125. Thurairajah K, Briggs GD, Balogh ZJ. The source of cell-free mitochondrial DNA in trauma and potential therapeutic strategies. Eur $J$ Trauma Emerg Surg. Epub 2018. April 9.

126. Nakahira K, Kyung SY, Rogers AJ, et al. Circulating mitochondrial DNA in patients in the ICU as a marker of mortality: derivation and validation. PLoS Med. 2013;10(12):e1001577.

127. Black GE, Sokol KK, Moe DM, et al. Impact of a novel phosphoinositol-3 kinase inhibitor in preventing mitochondrial DNA damage and damage-associated molecular pattern accumulation: results from the Biochronicity Project. JTrauma Acute Care Surg. 2017;83(4):683-689.
128. McNab A, Burns B, Bhullar I, Chesire D, Kerwin A. A prehospital shock index for trauma correlates with measures of hospital resource use and mortality. Surgery. 2012;152(3):473-476.

129. Mitra B, Fitzgerald M, Chan J. The utility of a shock index $\geq 1$ as an indication for pre-hospital oxygen carrier administration in major trauma. Injury. 2014;45(1):61-65.

130. Mutschler M, Nienaber U, Munzberg M, et al. The Shock Index revisited - a fast guide to transfusion requirement? A retrospective analysis on 21,853 patients derived from the TraumaRegister DGU(R). Crit Care. 2013;17(4):R172.

131. Camazine MN, Hemmila MR, Leonard JC, et al. Massive transfusion policies at trauma centers participating in the American College of Surgeons Trauma Quality Improvement Program. J Trauma Acute Care Surg. 2015;78(6 Suppl 1):S48-53.

132. Tonglet ML. Early Prediction of Ongoing Hemorrhage in Severe Trauma: Presentation of the Existing Scoring Systems. Arch Trauma Res. 2016;5(4):e33377.

133. Arakaki LSL, Bulger EM, Ciesielski WA, et al. Muscle oxygenation as an early predictor of shock severity in trauma patients. Shock. 2017;47(5):599-605.

134. Schenkman KA, Carlbom DJ, Bulger EM, et al. Muscle oxygenation as an indicator of shock severity in patients with suspected severe sepsis or septic shock. PLoS One. 2017;12(8):e0182351.

135. Schenkman KA, Hawkins DS, Ciesielski WA, Delaney M, Arakaki LS. Non-invasive assessment of muscle oxygenation may aid in optimising transfusion threshold decisions in ambulatory paediatric patients. Transfus Med. 2017;27(1):25-29.

136. Arakaki LS, Schenkman KA, Ciesielski WA, Shaver JM. Muscle oxygenation measurement in humans by noninvasive optical spectroscopy and locally weighted regression. Anal Chim Acta. 2013;785:27-33.

137. Holcomb JB, Tilley BC, Baraniuk S, et al. Transfusion of plasma, platelets, and red blood cells in a 1:1:1 vs a 1:1:2 ratio and mortality in patients with severe trauma: the PROPPR randomized clinical trial. JAMA. 2015;313(5):471-482.

138. Fahrendorff M, Oliveri RS, Johansson PI. The use of viscoelastic haemostatic assays in goal-directing treatment with allogeneic blood products - a systematic review and meta-analysis. Scand J Trauma Resusc Emerg Med. 2017;25(1):39.

139. Lopez E, Srivastava AK, Pati S, Holcomb JB, Wade CE. Plateletderived microvesicles: a potential therapy for trauma-induced coagulopathy. Shock. 2018;49(3):243-248.

140. Hickman DA, Pawlowski CL, Sekhon UDS, Marks J, Gupta AS. Biomaterials and advanced technologies for hemostatic management of bleeding. Adv Mater. 2018;30(4):1700859.

141. Centers for Disease C, Prevention. Fatal bacterial infections associated with platelet transfusions -- United States, 2004. MMWR Morb Mortal Wkly Rep. 2005;54(7):168-170.

142. Estcourt LJ, Malouf R, Hopewell S, et al. Pathogen-reduced platelets for the prevention of bleeding. Cochrane Database Syst Rev. 2017;7:CD009072.

143. Vamvakas EC. Relative safety of pooled whole blood-derived versus single-donor (apheresis) platelets in the United States: a systematic review of disparate risks. Transfusion. 2009;49(12):2743-2758.

144. Acker JP, Marks DC, Sheffield WP. Quality assessment of established and emerging blood components for transfusion. J Blood Transfus. 2016;2016:4860284.

145. Neisser-Svae A, Trawnicek L, Heger A, Mehta T, Triulzi D. Five-day stability of thawed plasma: solvent/detergent-treated plasma comparable with fresh-frozen plasma and plasma frozen within 24 hours. Transfusion. 2016;56(2):404-409.

146. Hess JR, Holcomb JB. Resuscitating PROPPRly. Transfusion. 2015;55(6):1362-1364.

147. Mayr WR. Haemovigilance: are there significant differences among plasma products? Transfus Apher Sci. 2010;43(3):407-409.

148. Pitkanen H, Jouppila A, Mowinckel MC, et al. Enhanced thrombin generation and reduced intact protein $\mathrm{S}$ in processed solvent detergent plasma. Thromb Res. 2015;135(1):167-174. 
149. Heger A, Neisser-Svae A, Trawnicek L, Triulzi D. Thrombin generation potential and clot-forming capacity of thawed fresh-frozen plasma, plasma frozen within $24 \mathrm{~h}$ and solvent/detergent-treated plasma (octaplasLG((R)) ), during 5-day storage at 1-6 degrees C. Vox Sang. Epub 2018 April 23.

150. USFDA. Available from: 2018; https:/www.fda.gov/downloads/ biologicsbloodvaccines/bloodbloodproducts/approvedproducts/ licensedproductsblas/ucm336161.pdf. Accessed May 18, 2018.

151. Chhibber V, Greene M, Vauthrin M, Bailey J, Weinstein R. Is group A thawed plasma suitable as the first option for emergency release transfusion? (CME). Transfusion. 2014;54(7):1751-1755.

152. Cooling L. Going from A to B: the safety of incompatible group A plasma for emergency release in trauma and massive transfusion patients. Transfusion. 2014;54(7):1695-1697.

153. Mehr CR, Gupta R, von Recklinghausen FM, Szczepiorkowski ZM, Dunbar NM. Balancing risk and benefit: maintenance of a thawed Group A plasma inventory for trauma patients requiring massive transfusion. J Trauma Acute Care Surg. 2013;74(6):1425-1431.

154. Winearls J, Campbell D, Hurn C, et al. Fibrinogen in traumatic haemorrhage: a narrative review. Injury. 2017;48(2):230-242.

155. Winearls J, Wullschleger M, Wake E, et al. Fibrinogen Early In Severe Trauma studY (FEISTY): study protocol for a randomised controlled trial. Trials. 2017;18(1):241.

156. Okerberg CK, Williams LA 3rd, Kilgore ML, et al. Cryoprecipitate AHF vs. fibrinogen concentrates for fibrinogen replacement in acquired bleeding patients - an economic evaluation. Vox Sang. 2016;111(3):292-298.

157. Kriebardis AG, Antonelou MH, Georgatzakou HT, Tzounakas VL, Stamoulis KE, Papassideri IS. Microparticles variability in fresh frozen plasma: preparation protocol and storage time effects. Blood Transfus. 2016;14(2):228-237.

158. Francis CW, Marder VJ. Increased resistance to plasmic degradation of fibrin with highly crosslinked alpha-polymer chains formed at high factor XIII concentrations. Blood. 1988;71(5):1361-1365.

159. Gerlach R, Tolle F, Raabe A, Zimmermann M, Siegemund A, Seifert $\mathrm{V}$. Increased risk for postoperative hemorrhage after intracranial surgery in patients with decreased factor XIII activity: implications of a prospective study. Stroke. 2002;33(6):1618--1623.

160. Karkouti K, von Heymann C, Jespersen CM, et al. Efficacy and safety of recombinant factor XIII on reducing blood transfusions in cardiac surgery: a randomized, placebo-controlled, multicenter clinical trial. J Thorac Cardiovasc Surg. 2013;146(4):927-939.

161. Nascimento B, Goodnough LT, Levy JH. Cryoprecipitate therapy. $\mathrm{Br}$ J Anaesth. 2014;113(6):922-934.

162. Key NS, Negrier C. Coagulation factor concentrates: past, present, and future. Lancet. 2007;370(9585):439--448.

163. Hauser CJ, Boffard K, Dutton R, et al. Results of the CONTROL trial: efficacy and safety of recombinant activated Factor VII in the management of refractory traumatic hemorrhage. J Trauma. 2010;69(3):489-500.

164. Murthi SB, Stansbury LG, Dutton RP, Edelman BB, Scalea TM, Hess JR. Transfusion medicine in trauma patients: an update. Expert Rev Hematol. 2011;4(5):527-537.
165. Kraut JA, Madias NE. Serum anion gap: its uses and limitations in clinical medicine. Clin J Am Soc Nephrol. 2007;2(1):162-174.

166. McCarron DA, Elliott WC, Rose JS, Bennett WM. Severe mixed metabolic acidosis secondary to rhabdomyolysis. Am J Med. 1979;67(5):905-908.

167. Kraut JA, Madias NE. Metabolic acidosis: pathophysiology, diagnosis and management. Nat Rev Nephrol. 2010;6(5):274-285.

168. Wolberg AS, Meng ZH, Monroe DM 3rd, Hoffman M. A systematic evaluation of the effect of temperature on coagulation enzyme activity and platelet function. J Trauma. 2004;56(6):1221-1228.

169. Kermode JC, Zheng Q, Milner EP. Marked temperature dependence of the platelet calcium signal induced by human von Willebrand factor. Blood. 1999;94(1):199-207.

170. Kramer L, Bauer E, Joukhadar C, et al. Citrate pharmacokinetics and metabolism in cirrhotic and noncirrhotic critically ill patients. Crit Care Med. 2003;31(10):2450-2455.

171. Kornblith LZ, Kutcher ME, Redick BJ, Calfee CS, Vilardi RF, Cohen MJ. Fibrinogen and platelet contributions to clot formation: implications for trauma resuscitation and thromboprophylaxis. JTrauma Acute Care Surg. 2014;76(2):255-263.

172. Asehnoune $\mathrm{K}, \mathrm{Ba} \operatorname{logh} \mathrm{Z}$, Citerio $\mathrm{G}$, et al. The research agenda for trauma critical care. Intensive Care Med. 2017;43(9):1340-1351.

173. Shukla M, Sekhon UD, Betapudi V, et al. In vitro characterization of SynthoPlate (synthetic platelet) technology and its in vivo evaluation in severely thrombocytopenic mice. J Thromb Haemost. 2017;15(2):375-387.

174. Harr JN, Moore EE, Ghasabyan A, et al. Functional fibrinogen assay indicates that fibrinogen is critical in correcting abnormal clot strength following trauma. Shock. 2013;39(1):45-49.

175. Jeger V, Willi S, Liu T, et al. The Rapid TEG a-Angle may be a sensitive predictor of transfusion in moderately injured blunt trauma patients. Scientific WorldJournal. 2012;2012:821794.

176. Jeger V, Zimmermann H, Exadaktylos AK. Can RapidTEG accelerate the search for coagulopathies in the patient with multiple injuries? $J$ Trauma. 2009;66(4):1253-1257.

177. Schlimp CJ, Solomon C, Ranucci M, Hochleitner G, Redl H, Schochl $H$. The effectiveness of different functional fibrinogen polymerization assays in eliminating platelet contribution to clot strength in thromboelastometry. Anesth Analg. 2014;118(2):269-276.

178. Kashuk JL, Moore EE, Sawyer M, et al. Postinjury coagulopathy management: goal directed resuscitation via POC thrombelastography. Ann Surg. 2010;251(4):604-614.

179. Kashuk JL, Moore EE, Wohlauer M, et al. Initial experiences with point-of-care rapid thrombelastography for management of lifethreatening postinjury coagulopathy. Transfusion. 2012;52(1):23-33.

180. Pommerening MJ, Goodman MD, Farley DL, et al. Early diagnosis of clinically significant hyperfibrinolysis using thrombelastography velocity curves. J Am Coll Surg. 2014;219(6):1157-1166.

181. Sheen JH, Heeger PS. Effects of complement activation on allograft injury. Curr Opin Organ Transplant. 2015;20(4):468-475.

182. Davis AE 3rd, Mejia P, Lu F. Biological activities of C1 inhibitor. Mol Immunol. 2008;45(16):4057-4063.
Journal of Blood Medicine

\section{Publish your work in this journal}

The Journal of Blood Medicine is an international, peer-reviewed, open access, online journal publishing laboratory, experimental and clinical aspects of all aspect pertaining to blood based medicine including but not limited to: Transfusion Medicine; Blood collection, Donor issues, Transmittable diseases, and Blood banking logistics; Immunohematology; Artificial and alternative blood based therapeutics; Hematology; Biotechnology/nanotechnology of blood related medicine; Legal aspects of blood medicine; Historical perspectives. The manuscript management system is completely online and includes a very quick and fair peer-review system. Visit http://www.dovepress.com testimonials.php to read real quotes from published authors. 